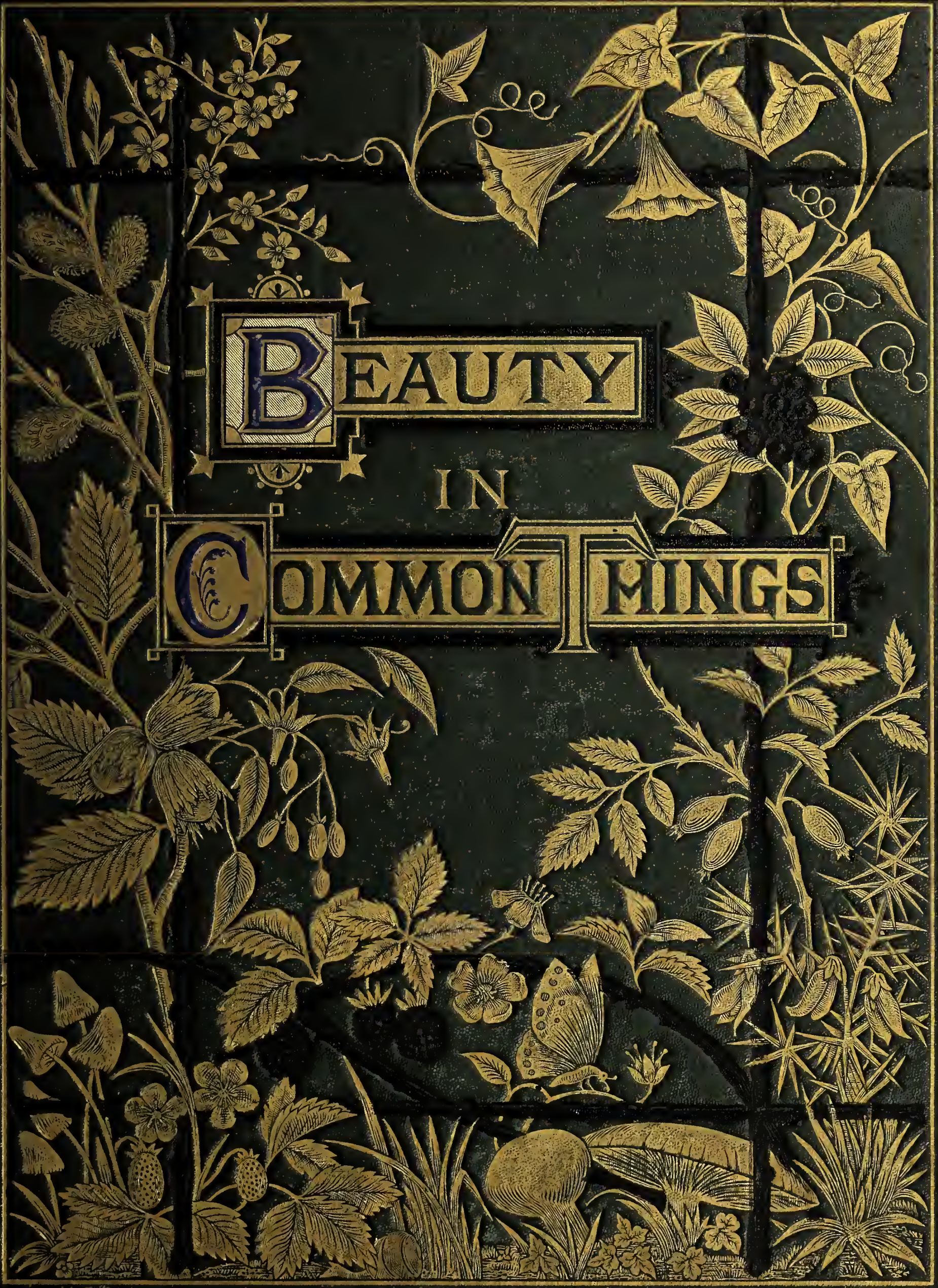




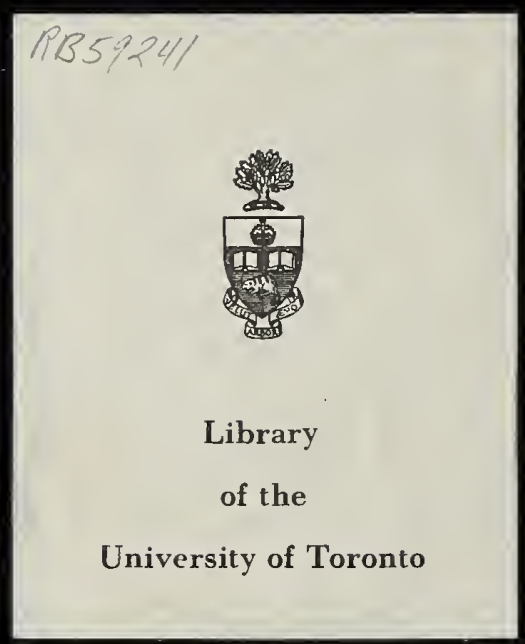


May 1846

Shelluig Bee. Puje.

araced $t$

L. S. larh. 


$$
\text { - Text 2., tarss A.C. Chambers }
$$

Digitized by the Internet Archive in 2017 with funding from University of Toronto

https://archive.org/details/beautyincommonth00cham 


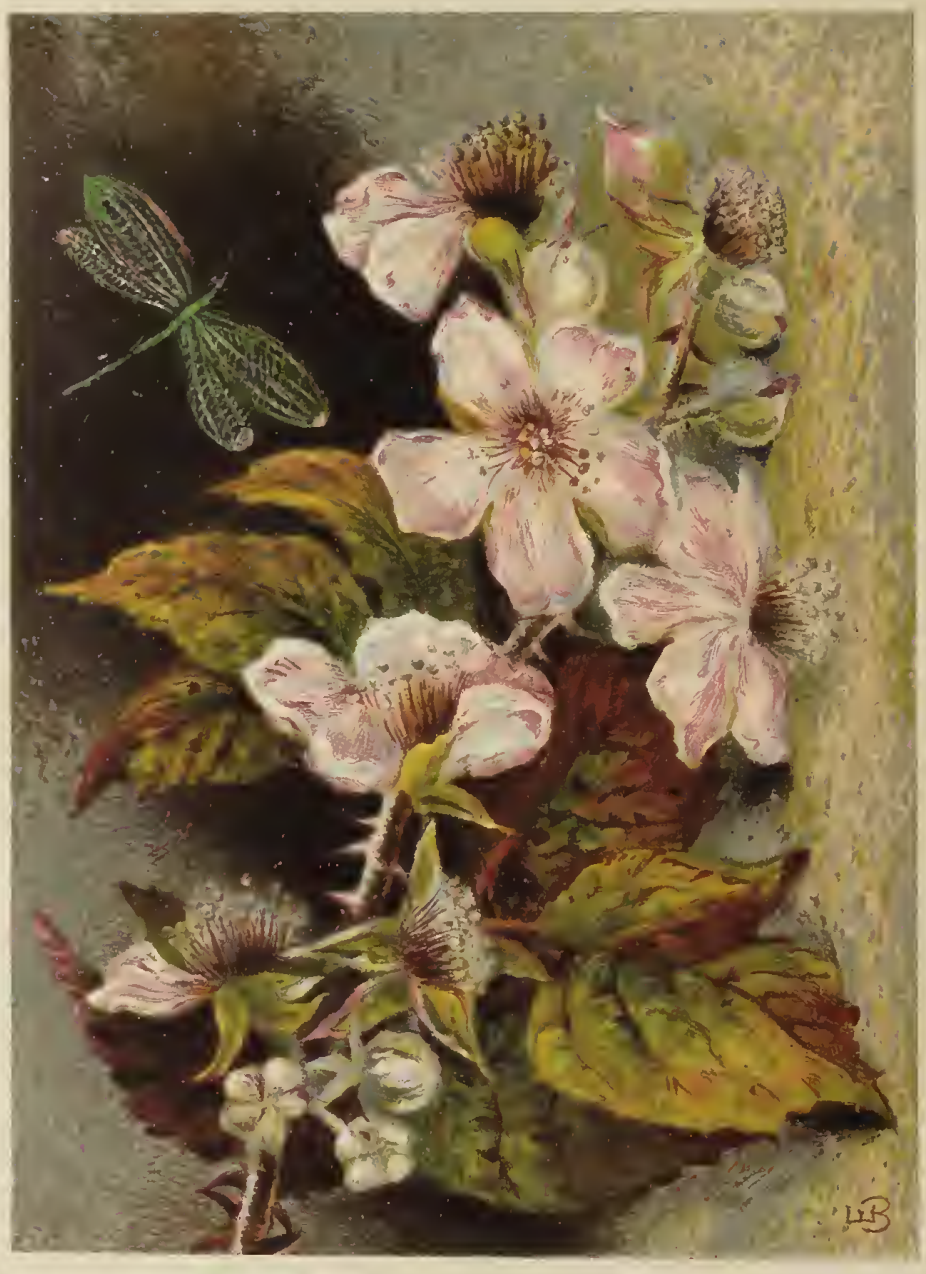




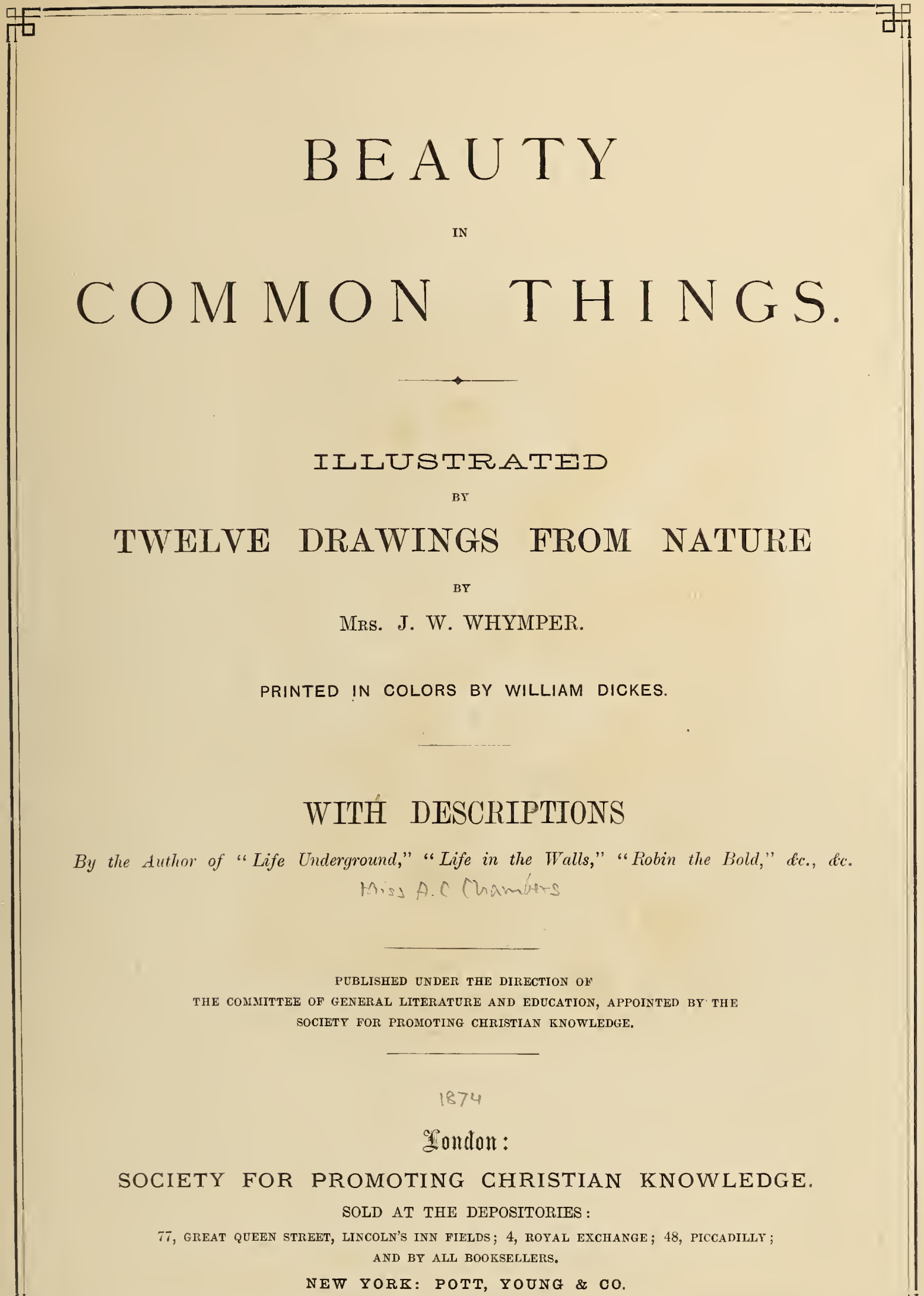

NEW YORK: POTT, YOUNG \& CO. 
LONDON:

Jas. Trubco'Tt aND SoN

Printed bx Jag. Trubco't
Suffolk Lane, City. 


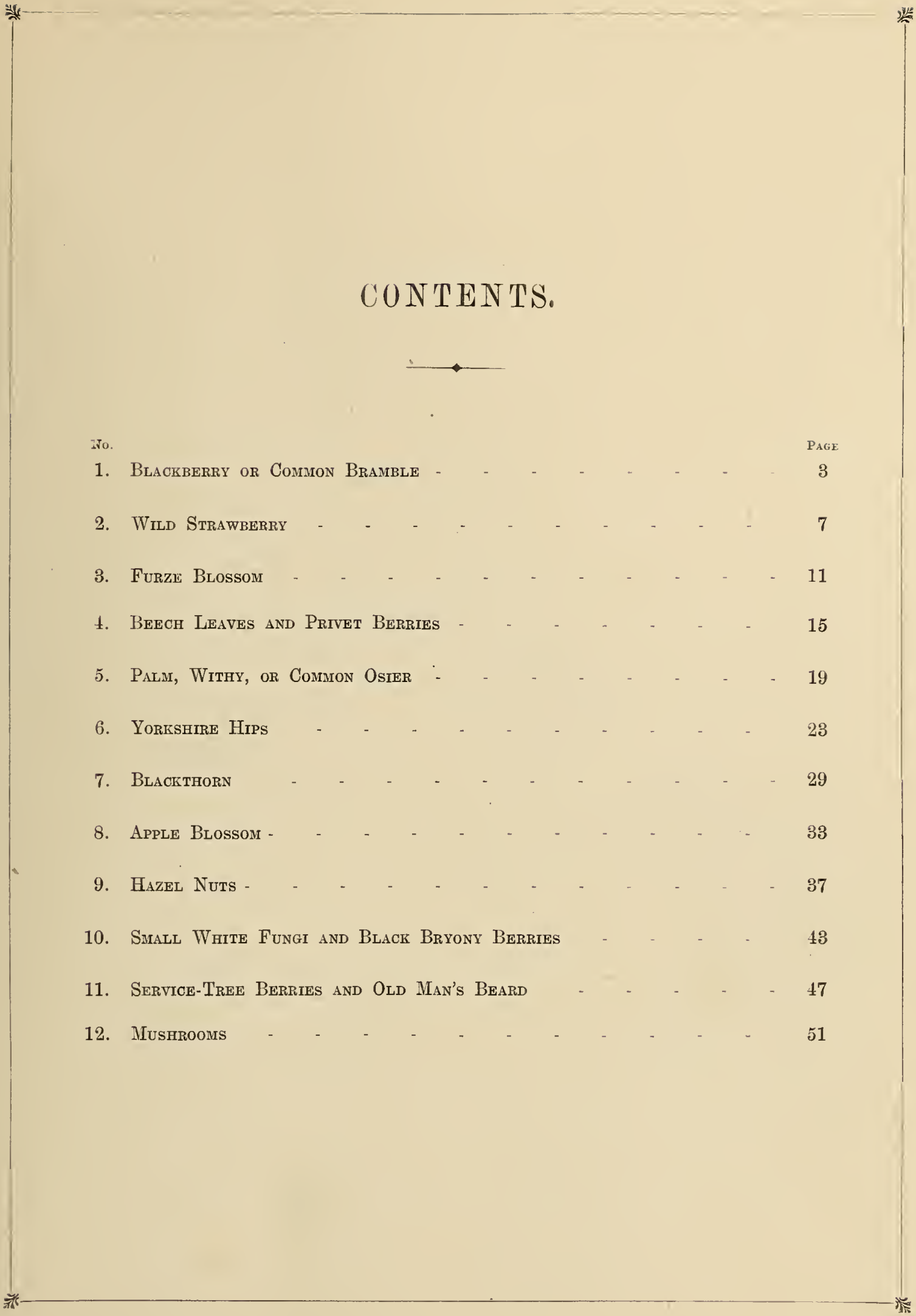





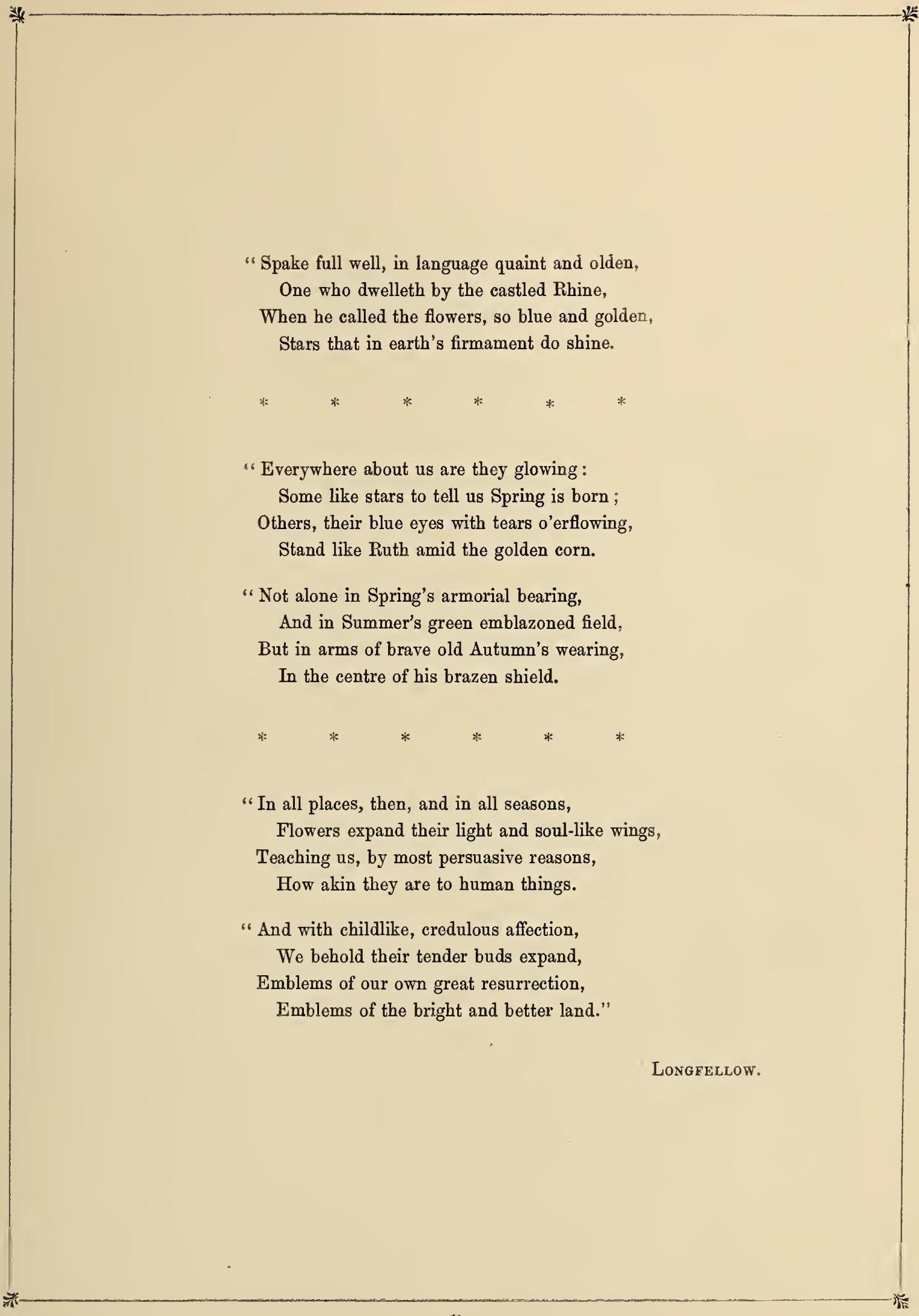




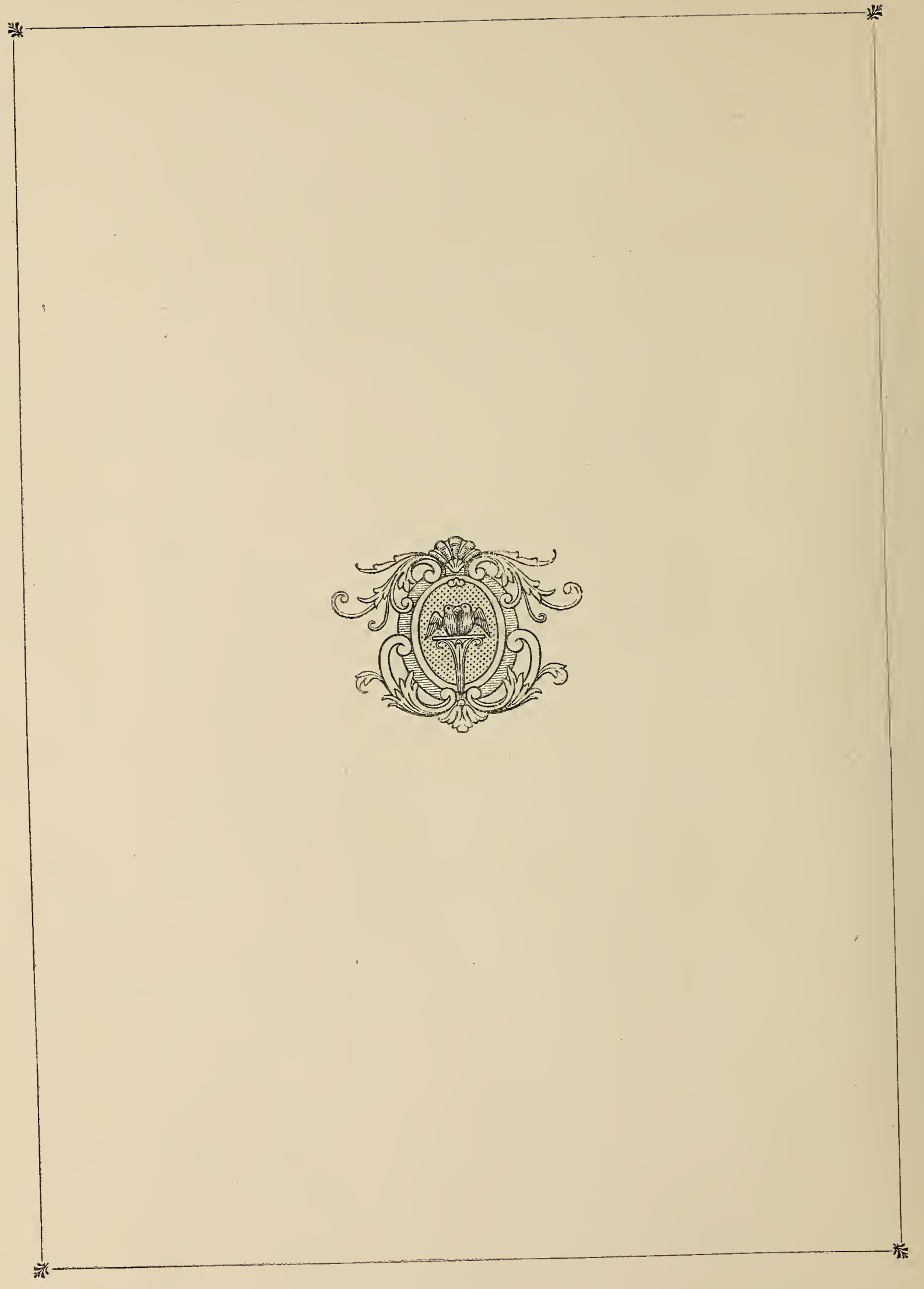




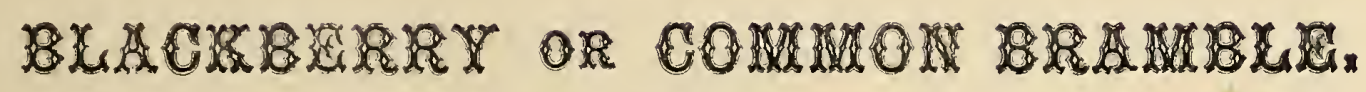

\section{(Rubus Fruticosus.)}

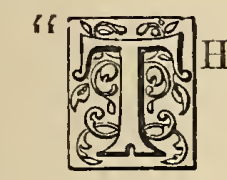

HE common bramble bringeth forth slender branches, long shoots, easily bowed, tamping* among hedges and whatsoever stands near unto it, armed with hard and sharp prickles, whereon do grow leaves consisting of many, set upon a rough middle rib, green on the upper side, and underneath somewhat white. On the tops of the stalks stand certain flowers, in shape like those of the briar rose, but lesser ; of colour white, and somewhat washed over with a little purple. The fruit or berry is like that of the mulberry, first red, then black, when it is ripe ; in taste between sweet and sour, very soft, and full of grains."

Such is the very correct description given by John Gerarde, the old English herbalist of the sixteenth century, of the most common of our native shrubs. The bramble is found over the whole of the United Kingdom. Its varieties are many; the prevailing one in the south of England is that known by botanists as Rubus discolor, a name derived from the very dark green of the upper surface of the leaf, contrasted with the white hairy under surface. This feature is common to the other varieties, but not to the same degree. Some are remarkable for the largeness and juiciness of the berry. These grow for the most part on the southern coast and in Devonshire.

Though appreciated by most persons, both in its natural state and when made into a conserve with sugar, perhaps few are aware of its remarkably wholesome qualities, owing to its being, unlike many kinds of fruit, antacid. It can therefore be eaten with impunity, if used simply, by persons who find other sweets disagree, and is very useful in certain com-

* Derived from "tamper," a word of uncertain etymology, meaning intermeddling, getting mixed up with. 
plaints. This quality is neutralised by the practice of mixing apple juice with the simple bramble to give it a more acid flavour.

The buds of the bramble leaves boiled in spring water, and the decoction sweetened with honey, are good, the old herbalists tell us, for sore throats.

The blackberry flowers in July and August, thus affording the wellknown berries the advantage of the long-settled heat of the harvest sunshine, wherein to ripen, when the leaves already show symptoms of changing colour.

"Thy fruit full well the schoolboy knows,

Wild bramble of the brake;

So put thou forth thy small white rose,

I love it for his sake.

"Though woodbines flower and roses glow

0 'er all the fragrant bowers,

Thou need'st not be ashamed to show

Thy satin-threaded flowers.

"For dull the eye, the heart as dull,

That cannot feel how fair,

Amid all beauty beautiful,

Thy tender blossoms are."

Ebenezer Elliott.

It may safely be averred that partiality for the bramble bush is not confined to the schoolboy. To all accustomed to an English country life it carries with it not only its own individual beauty, that of the wlite, rosy-tinted clustered blossoms, and serrated, downy leaves, but conjures up reminiscences of long, bright autumn days, when we have wandered through woods, by hedgerows, and over heathy commons, enjoying the mild warmth of the "blackberry summer," and lingered in the golden haze of a September sunset, to fill one more basket, or search one more promising bush.

"When earth repays with golden sheaves

The labours of the plough,

And ripening fruits and forest leaves

All brighten on the bough."

WORDSWORTH. 
It is said by Pliny that the bramble bush suggested to the ancients the propagation of trees by layers. They "held the notion that both the flower and fruit of the bramble were efficacious against the bite of serpents ; and that the young shoots, eaten as salad, served to fasten loose teeth, was an old fancy in our own country. The green twigs lave been used for dyeing. The stems are employed for thatching cottages."

Gerarde also calls this shrub, "raspis," or " hindbcrry," and the wild raspberry is the head of the tribe; but that it was early recognised under its present name we know from the almost classic poem of the "Babes in the Wood," which dates from 1595 :

"Their prettye lippes with blackberries

Were all besmeared and dyed;

And when they saw the darksome night,

They sat them down and eryed."

Dr. Prior (Popular Names of British Plants) says the name of bramble is derived from the Anglo-Saxon bremel, brembel, or braembel, signifying prickly or thorny bushes.

The word translated "bramble" in our version of Scripture, represents accordingly various kinds of thorny slurubs or weeds, having nothing in common, necessarily, with our blackberry. The fruit of the blackberry is best gathered at midday, when the sun has been on it for some hours, and is said not to be in a perfect state until it has had the first breath of frost.

The beautiful insect seen on one side of our illustration is one of the many species of the interesting race of dragon-flies, about which much more might be said than our space will allow.

They vary much in colour, but the general characteristics of the different kinds are, that they are "fiercely predaceous," a peculiarity from which their name is derived, they being verily dragons of the air to other insects, "strong of wing and gifted with glittering colours." The wonderful contrast between their appearance and habits, except in point of voracity, in their larval and pupal states, when they inhabit muddy ponds, and their glorious transformation at the appointed time into the magnificent insect that sails through the air, arrayed in blue, green, crimson, or purple, forms, however, their chief interest and attraction with those who love to trace 
spiritual analogies in the processes of nature. The larva of the dragon-fly is described as "a somewhat uncouth, broad, flat, olive-coloured animal, rather spider-like, having six sprawling legs, which crawls about the mud at the bottom of ponds, or glides by a singular mechanism through their waters." This mechanism has been compared to the way in which the nautilus forces itself through the waters. By means of an apparatus, consisting of several pointed flakes covering the opening of a large cavity, water is admitted into the body, and again forcibly cjected, after the oxygen necessary for the creature's breathing has becn extracted from it. By this action the insect is driven onwards.

Its physiognomy must be most terror-inspiring to its aquatic neighbours, for the lower lip is extended downwards, and then expanded into a sort of plate, attached to it by a joint, so that it can be folded upwards at will, and cover about half the face. To the end of the latter plate are fastened two others, so broad as to fold over the upper part of the face, and this formidable mask is furnished on each side with a pair of forceps, by which it can grasp at objects with unerring and deadly aim. The period passed in the preliminary stages is ten or eleven months, after which the creature betrays aspirations after a higher form of existence, and, crawling up the stem of some stalk growing in its native element, awaits its release from the thraldom of its grosser nature, when "its slender, burnished body, more brightly blue than the deep blue sky, glistens in the sunbeams, and its net-like wings laugh at the flowers becausc they cannot fly."

Dragon-flies are called, by country peoplc, "horse-stingers ;" but this is founded on a popular error, as they have no sting, and do not annoy horses.

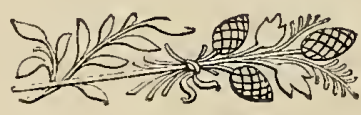




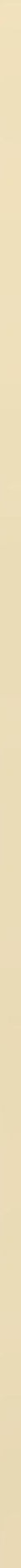




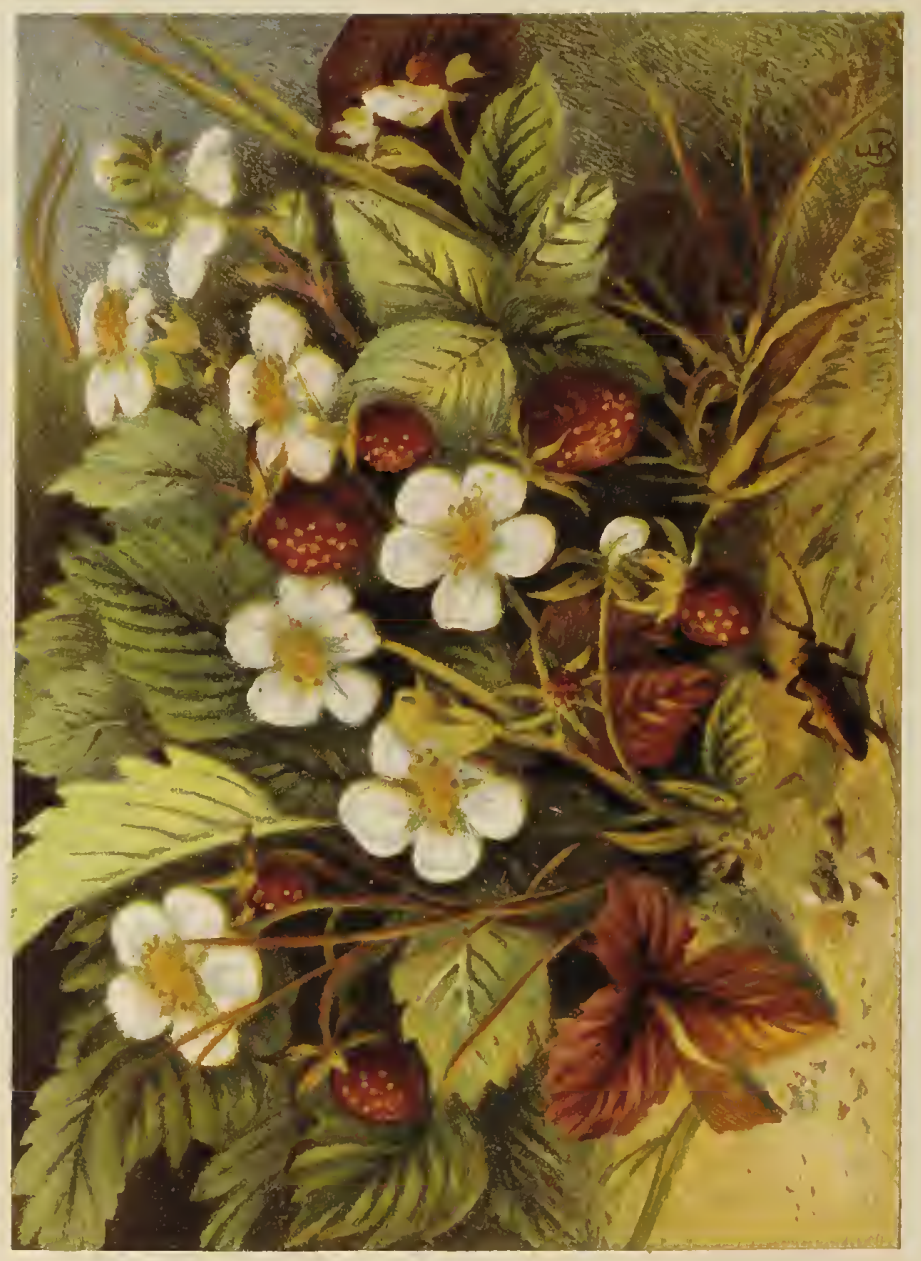




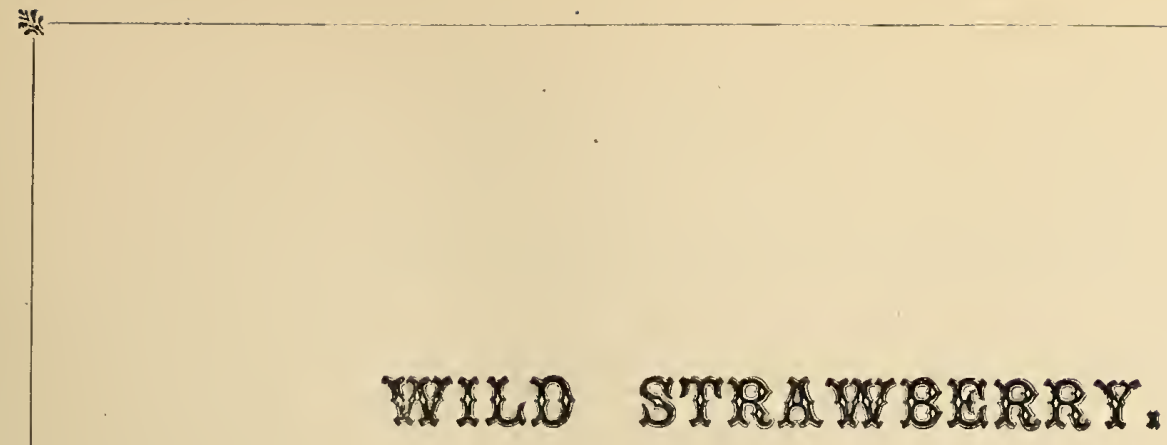

(Fragaria Vesca.)

HE Wood Strawberry, with its small white petals and drooping
scarlet fruit, from the fragrance of which the botanic name is
derived, is said to be the origin of the cultivated plant.

Although called a berry, the round red fruit is not one, strictly speaking, for true berries contain seeds. The strawberry is one of those plants the fruit of which consists of the receptacle or point at which all the parts of the flower meet, enlarged to a juicy pulp. The little yellow seeds, or "achenes" as they are called, for each encloses a single little seed, are botanically the true fruit of the plant, and, supposing the strawberry to remain unplucked, "wasting its sweetness on the desert air," they would retain their reproducing character long after the delicious pulp on which they are borne had dried up and vanished. The strawberry, as well as the raspberry, pear, peach, and many similar flowers, is one of a tribe of peculiar beauty, the rosaceæ, very many of which are fruit-bearing plants, all innocuous in their nature, though not equally acceptable to the palate, such as the hawthorn, mountain ash, wild rose, wild cherry, \&c.

It is very fond of spreading its slender shoots or runners on dry banks and on the sides of shady watercourses, and most of us can remember some rocky woodland track and retired nook of which it may be said-

" There bloomed the strawberry of the wilderness;

The trembling eyebright showed her sapphire blue;

The thyme her purple like the breath of even :"

or a grotto fringed with the pendulous berries, like those accused by Canovés dragon-fly of having drunk so deep of the evening red that their heads were quite heavy.

The native fruits of our island are not many. We have the raspberry, 
blackberry, cranberry, bramble, and cloudberry, the last being a variety of the family Rubus, known as the "mountain bramble." They are all wild and delicately flavoured, but, except the blackberry, are for the most part confined to heathy or mountainous districts, whilst the strawberry, sweeter and more fragrant than any, may be found in most undisturbed shady localities. The large cultivated fruit is so mucl more in request that the native of the woods is left for the enjoyment of those whose lot it is to wander in out-of-the-way, old-fashioned country scenes. In poetry it is associated with elf-haunted woods and rippling streamlets, and those who like to revel in fairy lore may well indulge the fancy so prettily expressed in Mary Howitt's little poem of "Mabel on Midsummer's Day," that its slender stalks and dainty white blossoms are under the special protection of the fairy folk.

"And when she came to the lonesome glen,

She kept beside the burn,

And neither pluck'd the strawberry flower,

Nor broke the lady fern.

"And then she heard a little voice,

Shrill as the midge's wing,

That spake aloud-'A human child

Is here-yet mark the thing !

" " The lady fern is all unbroke,

The strawberry flower unta'en;

What shall be done for her who still

From mischief can refrain?'

" ' Give her a fairy cake,' said one ;

'Grant her a wish,' said three;

'The latest wish that she hath wish'd,'

Said all, "whate'er it be.",

Perhaps the lesson signified by the fairies' commendation of the good and thoughtful child is after all the same as that contained in Wordsworth's "Foresight," from which it is easy to derive a higher moral:

"Strawberry blossoms one and all,

We must spare them-here are many;

Look at it, the flower is small,

Small and low, tho' fair as any. 
"Primroses the spring may love,

Summer knows but little of them;

Violets, a barren kind,

Wither'd on the ground must lie.

Daisies leave no fruit behind,

When the pretty flowerets die;

Pluck them, and another year

As many will be blowing here.

"God has given a kindlier power,

To the favour'd strawberry flower.

Hither, soon as spring is fled,

You and $I$ and Charles will walk :

Lurking berries ripe and red

Then will hang on every stalk,

Each within its leafy bower ;-

And for that promise spare the flower."

The strawberry leaf, as is well known, is a heraldic distinction on ducal coronets, but the origin of its use in this way is obscure. The first instance of its appearance is on the bascinet of Edward the Black Prince on his statue at Canterbury.

The strawberry was esteemed in former times not only for its beauty and agreeable taste, but for the wholesome quality of its leaves, an infusion of which was said to be good for soreness in the mouth or throat.

Culpepper recommends ripe strawberries as a safe dentifrice, undeniably pleasant, and adds the agreeable opinion that it is a fruit "in eating" of whiclı you can scarcely indulge to excess."

The name is supposed by some to be derived from the old practice of selling the fruit threaded on straws, but Dr. Prior says it dates from an earlier period than any at which wild strawberries are likely to have been marketable, and thinks it owes its origin to the Anglo-Saxon streowberie, either from its straw-like haulms, or from their lying strewn on the ground.

The beetle portrayed in our illustration is that popularly known as the Skipjack, or Spring Beetle, from thcir peculiar power of turning head-overheels and leaping in the air, a feat they perform by means of an interior apparatus consisting of a tooth or spine extending in the shape of a bow from the breast to the stomach. This spring can only be used when the creature lies on its back. By pressing down its head and tail and pushing 
BEAUTY IN COMMON THINGS.

out the breast, the spine resists the pressure till it is violently driven out, the recoil jerking the insect into the air and enabling it to regain its footing. The noise made by this performance has also given the creature the name of "Click Beetle." It is harmless in its perfect state, feeding only on the juices of flowers, but is to be dreaded as the parent of the wire worm, a most voracious and destructive grub. It attacks the roots and every part of almost any herbaceous plant that it can reach below the surface of the ground, being particularly partial to wheat. Like most other beetles, it undergoes three or four changes after it emerges from the egg in the appearance of a short semi-transparent thread, from which probably its name of wire worm is derived.

From the first it commences its wholesale vegetable destruction, burying its head in the heart of the stalk of whatever plant it attacks, about an inch below ground. Its dimensions increase to twice its size on each change of coat, and when full grown it is of a pale yellowish colour, with a few scattered hairs on its shining skin. It undergoes its chrysalis state considerably below the surface of the soil, a manœurre which often misleads into the idea that it has disappeared. After a period varying from a fortnight to one or two years, but always at the same season of the year, it develops into the little brown beetle before us. At first it appears pale, soft, and tender, but exposure to light and air hardens it, and it becomes black, brown, or parti-coloured, according to the species to which it belongs.

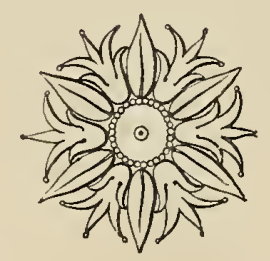




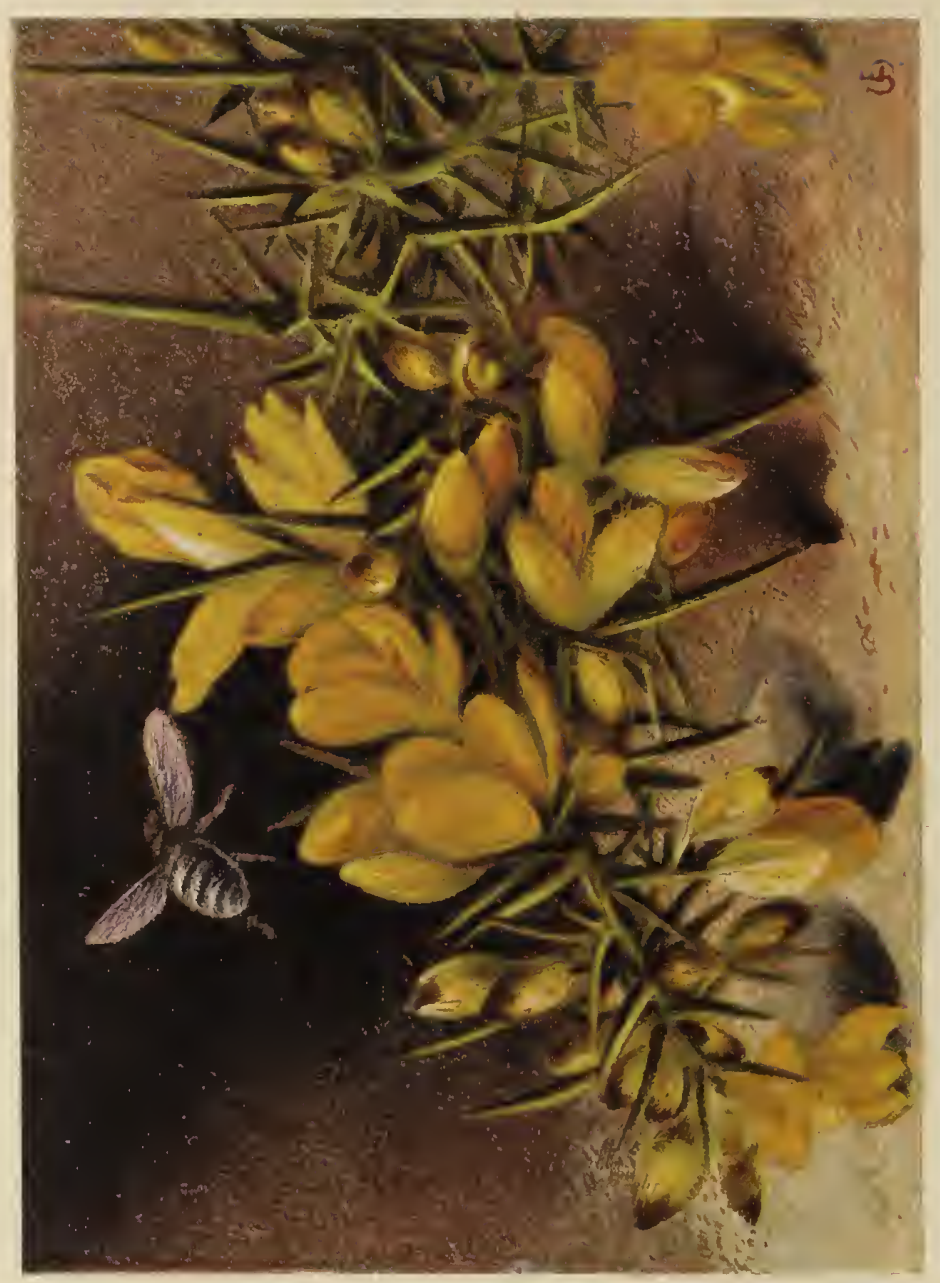




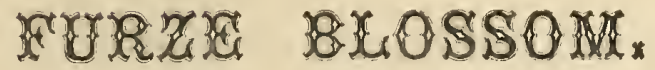

(Ulex Europous.)

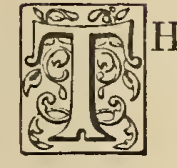

HIS shrub, called indiscriminately furze, whin, or gorse, is a native of Great Britain, renowned for its mass of golden flowers covering its bushy, thorny shrub, and relieving the eye on dry and often otherwise barren moors-

\section{"Hanging islands of resplendent furze."}

It is a well-known story that when Linnæus first behcld this plant, which he had never seen in his own more northern land, he fell on his face and thanked God for having brought him to the sight of such beauty, inferring the richer loveliness of the cultivated lands from the fact that the barren ground was thus clothed.

But the "golden islands," as they are truly described, of furze buslies, and their delicate fragrance, are inseparably connected in our minds with the first burst of really genial spring, and we are here reminded of the power of association as the hidden source of our conception of beauty, so ably dilated on by Sir Thomas Dick Lauder in his essay on the nature and principles of taste, prefixed to his edition of Gilpin's Forest Scenery.

He remarks, "We shall seek in vain in the accidents of mere organic matter for the sources of that vernal delight and joy which subject all finer spirits to an annual intoxication, and strike home the sense of beauty even to hearts that seem proof against it under all other aspects.

"The simple and universal pleasures that are diffused by the mere temperature of the air, and the profusion of sustenance; the pairing of birds, the cheerful resumption of rustic toils, the great alleviation of all the miseries of poverty and sickness, our sympathy with the young life and the promise and the hazards of the vegetable creation-the solemn yet 
cheering impression of the constancy of Nature to her great periods of renovation, and the hopes that dart spontaneously forward into the new circle of exertions and enjoyments that is opened up by her hand and her example. Such are some of the conceptions that are forced upon us by the appearances of returning spring, and that seem to account for the emotions of delight with which these appearances are hailed by every mind endowed with any degree of sensibility, somewhat better than the brightness of the colours or the agreeableness of the smells which are then presented to our senses."

The furze bush is the favourite residence of many small birds, animals, and insects, which find their domiciles more securely protected by its dense prickly branches than by many other shrubs.

The bee, which is represented beside our furze blossom, in its rich black and orange dress, is a specimen of the Mason or Lapidary Bee, the same as the "red hipped humble bee," which Cobweb the fairy was commissioned to kill and rob, albeit not on the top of a thistle. She is most likely pursuing her architectural labours in the crevice of some rocky boulder on the waste ground in the neighbourhood, and has paused to gather some of the pollen and honey for the future sustenance of her mortar-imbedded progeny.

There are found on the furze bush, not univcrsally but exclusively, a species of insect called the "Furze mite." They are mostly red, the favourite livery of these minute animals, but often of a dark green hue, according to the different stages of their growth, as they change their skins frequently during their development. They live in societies on the furze bushes under a tent-shaped web of a bluish colour, which they spin very quickly, hundreds of spinners uniting in joint action, crossing and re-crossing each other in every direction. Their home, which is formed at the apex of a twig of furze, appears to be made for the purpose of protection from the weather, and probably from other insects during the process of casting their skins, and not for capturing prey, as they live on the furze. They work busily throughout the day, and at night withdraw round the stem on which their web is formed, underneath its shclter. They multiply rapidly, but do not appear ever to leave their colony voluntarily, and are decidedly rare.

$$
\text { * “Midsummer Night's Dream." }
$$


Cattle which browsc on wild pastures are particularly fond of the young juicy shoots of the furze, the young stems having at first no prickles. They are "clothed with leaves from trrelve to twenty in number, shortly petiolate and trifoliate, consisting each of threc small elliptical, hairy, articulated leaflets. When the stcm becomes five or six inches in length, usually, the trifoliate leaves cease to be developed, and spines are then produced" (Prof. Lawson).

In order to promotc the rapid growth of these young shoots for pasture, it is the custom in Highland districts to set fire to the old bushes early in the year, and the conflagrations thus caused are very picturesque after dark in the spring evenings, shedding a lurid glare over the dark moor, now in onc spot, now in another, which is sometimes alarming to the uninitiated.

This practice, which extends to the heather, is alluded to by Sir Walter Scott in the Lady of the Lake, Canto III.:

"Not faster o'er thy heathery braes,

Balquidder, speeds the midnight blaze;"

and in a notc he remarks that "the custom, execrated by sportsmen, produces occasionally the most beautiful nocturnal appearances, similar almost to the discharge of a volcano."

For the protection of the wild game, it is not allowed after a certain period.

The gorse is much used as hedgewood on light, barren land, and is also greatly valued as provender for horses.

Its medicinal properties, the old herbals say, are much the same as those of broom, but in a lcss degree. It is said to be useful in dropsy and jaundice.

"Great heat or cold is alike unfavourable to this plant. In general it will not thrive further to the south of Europe than Provence, while in the regions of the north it is unknown as a wild flower. In Russia it is sometimes reared in the greenhouse, and it is also regarded in Sweden as a tender plant."

The name of furze appears to be of obscure derivation, but may be, Dr. Prior thinks, from fir, these bushes being, like the coniferous trees, a common firewood or fuel. 
"Gorse is from the Anglo-Saxon gorst, Welsh gores or gorest, a waste. Whin from the French guinda or guindoula, a word that generally means a cherry; but in Languedoc is applied to the jujube (Ziziphus*), a name extended to other thorny or prickly shrubs."

* Of which the crown of thorns is supposed to have been made.

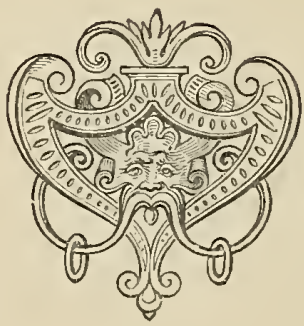





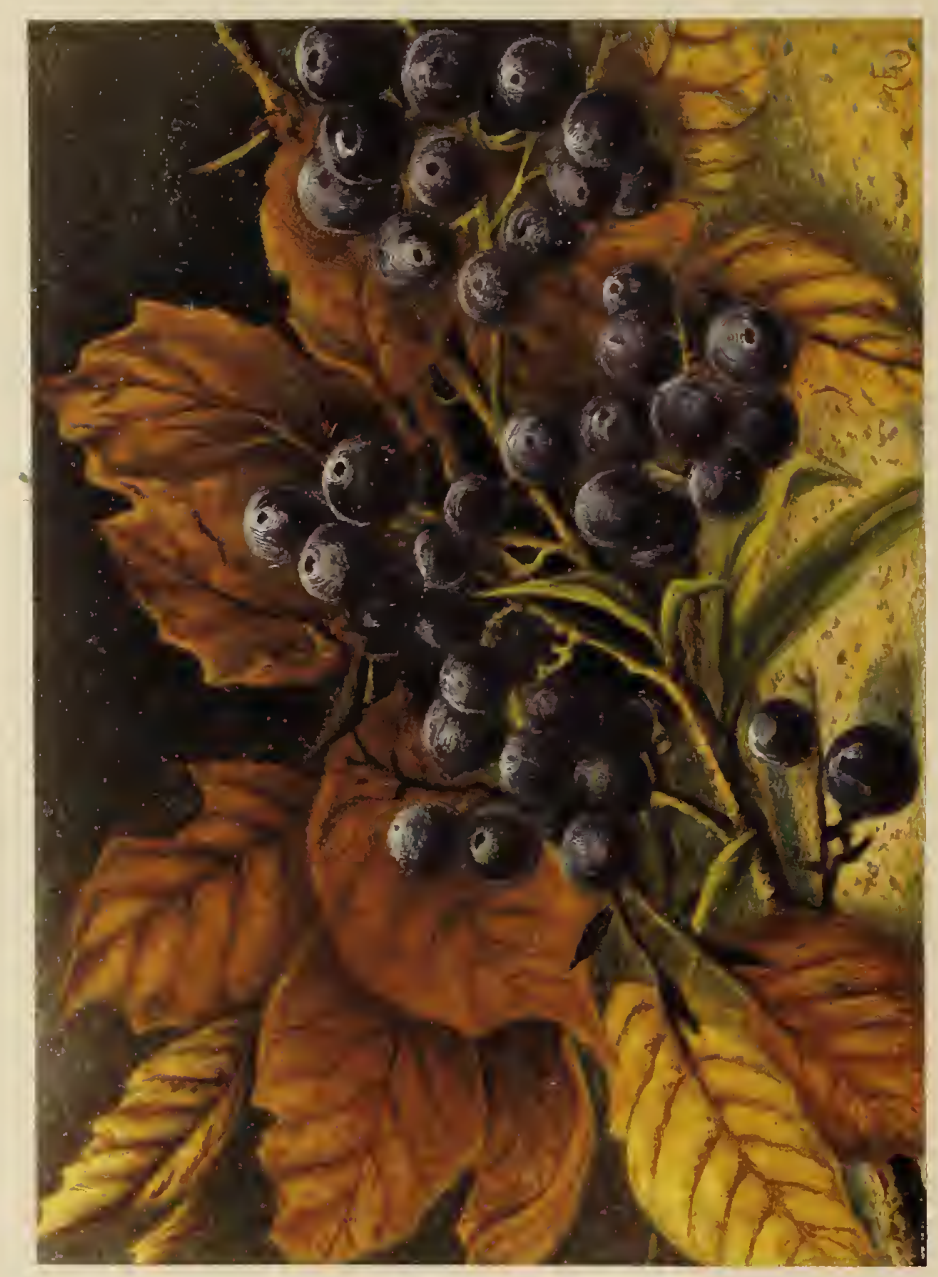




\title{
8)
}

\author{
(Fagus Sylvatica.)
}

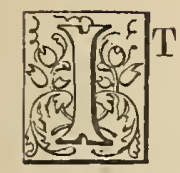

has been truly said of this far-famed tree, that it vies with the oak in stateliness and grandeur. Its stem grows to a great size. Its spreading branches and soft flowing foliage are associated in our minds with ancestral English parks and forest glades.

"The woodland calm is pure:

I cannot choose but have

A thought from these of the beechen trees

That in our England wave."

When first decked in its summer robes, the delicate bright green of its glossy leaves seems almost transparent as they flutter in the breeze, with the summer sunlight glinting through them; and the autumnal splendour of the tree is a thing of renown. As Longfellow expresses it-

\footnotetext{
"There is a beautiful spirit breathing now

Its mellow richness on the clustered trees;

And, from a beaker full of richest dyes,

Pouring new glory on the autumn woods."
}

The leaf of the beech forms, indeed, its chief beauty at any season of the year; and even Gilpin, who criticises it, as it appears to us, very unjustly, says of it-

"We see in beeches of happy composition the foliage falling in large flocks or layers elegantly determined, between which the shadows have a very forcible effect, especially when the tree is strongly illumined."

He remarks also, with regard to its autumnal hues,-

"Sometimes it is drest in modest brown, but generally in glowing orange, and in both dresses its harmony with the grove is pleasing. About 
the end of September, when the leaf begins to change, it makes a happy contrast with the oak, whose foliage is yet verdant. Some of the finest oppositions of tint which perhaps the forest can furnish arise from the union of oak and beech."

It has been remarked that "the leaf of cvery tree possesses individuality, and the aggregate of leaves makes up the character by which the tree is known." Thus the leaves of such trees and shrubs as are clothed from their base have a very short foot-stalk, or none at all, whilst trees with a bare trunk wear leaves with a long stalk. The beech-tree is fcathered with branches from the ground, and accordingly the leaves have scarcely any petiole.

Evelyn says of this tree, that "its very leaves, which make a natural and most agreeable canopy all the summer, being gathered about the fall and somewhat before they are much frost-bitten, afford the best and easiest mattresses in the world, to lay under our quilts instead of straw, because, besides their tenderness and loose lying together, they continue sweet for seven or eight years, long before which time straw becomes musty and hard. Thus they are used by divers persons of quality in Dauphiné and in Switzerland. I have sometimes lain on them to my great refreshment."

This old-fashioned couch is now superseded everywhere by the spring beds so universal on the Continent; but until their introduction, beech-leaf mattresses were still in common use; and Sir T. Dick Lauder corroborates the truth of Evelyn's remarks, adding that " the fragrant smell of green tea which the leaves retain is most gratifying."

The bark of the beech is smooth and silvery, and its wood ranks next to the oak and ash in point of utility, being much in request by cabinetmakers and turners for making various articles of household furniture. It is excellent also as fuel, and even the very shavings can be used for fining wines.

"The timber lasts long when kept wet, and is therefore wcll adapted for the sills and floors of locks, for the keels of vessels, and for the planking in the parts kept under water" (Sir T. D. Lauder).

The old trees that have grown to a large size are naturally most in request; and the plea urged in the name of the beech-tree by the poet to the woodcutter is probably the last that would avail for its preservation with persons impervious to poetic sentiment:- 


\section{"Thrice twenty summers I have seen \\ The sky grow bright, the forest green; \\ And many a wintry wind have stood \\ In bloomless, fruitless solitude."}

We must not omit alluding to the nuts of the beech, commonly called beech-mast.

The beech is one of those trees which bear barren and fertile flowers separately, the former in a roundish catkin, the latter stalked, with a double calyx, the onter containing two or three flowers. When the nuts are developed they are found attached to the base of the outer calyx, and crowned by the upper. Their shells are angular and leathery.

The primary use of the mast is to fatten swine and deer, and to provide sustenance for squirrels and other wild animals, but it has been often used as a substitute for bread, to which fact there is probably a reference in the botanic name, from phago, to eat.

Evelyn says that Chios endured a memorable siege by the use of it; and in some parts of France, in his time, they ground the bark in mills, and cxtracted a sweet oil, which the poor people eat willingly. It is said to be used in Picardy and elsewhere instead of butter, but may cause pain and nausea in some persons. When roasted and ground, the mast has also been made into coffee. The beech flourishes best in chalky or limestone soils, as in Surrey, Kent, and on the Cotswold and Stroudwater hills. It is very fine in Hereford and Monmouth, and also in the north. On the banks of the Wye it is much used for charcoal. It is said, however, that the finest beech-trees in England are in Hampshire.

There is a tradition among the natives of the forest of St. Leonards, Sussex, where thcre are also very fine beech-trees, that that saint, being unable to rest beneath their shade, owing to the snakes by day and the nightingales by night, prayed that both one and the other might be banished, since when-

\section{"The viper has ne'er been known to sting, Or the nightingale e'er heard to sing,"}

in that locality

The name of beech is said to be derived from the Anglo-Saxon Boc, bece, beace, a word which appears under various forms and dialects in the 
Dutch, old Norse, Swedish, Danish, and both old and modern German, with the same signification, though differing in gender, viz., a book and a beachtree. "From Runic tablets, the books of our ancestors having been made of this wood" (Prior).

From the smoothness of its bark, no tree has been more favoured with romantic inscriptions.

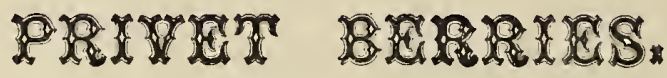

(Ligustrum Vulgare.)

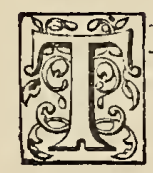

to turn.

The privet is valued as a thick, woody shrub, for forming dense, compact hedges, though there is nothing very interesting about its little, prim white flowers. They make the shrub look well, however, when in flower, as they grow in tufts at the ends of the branches.

It grows fast and thick, about four feet in height, and is raised from cuttings. Its small, dark green leaves often remain on the branches through the winter.

The berries are bitter and nauseous, and are said to dye a fine permanent green.

The tops of the flowers, when just beginning to bud, if infused in water, and mixed with honey and red wine, are a specific, we are told, for an ulcerated mouth or throat.

The name of privet seems to be a corruption of prymet, shortened from prime printemps, the old name for primrose. Some confusion seems to have arisen between the herb and the shrub, from "the Latin name Ligustrum having been applied to both by medieval writers" (Prior). 



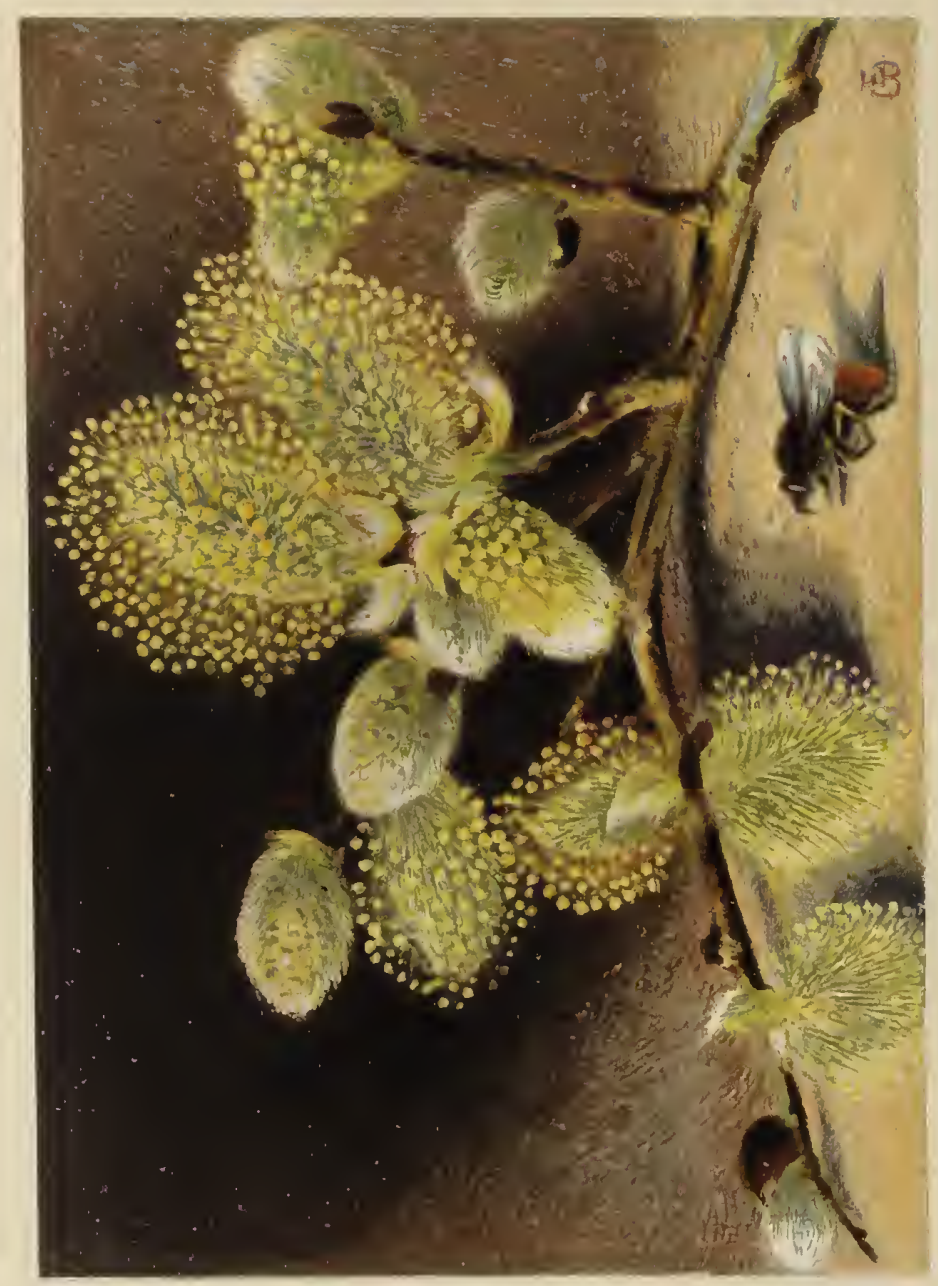




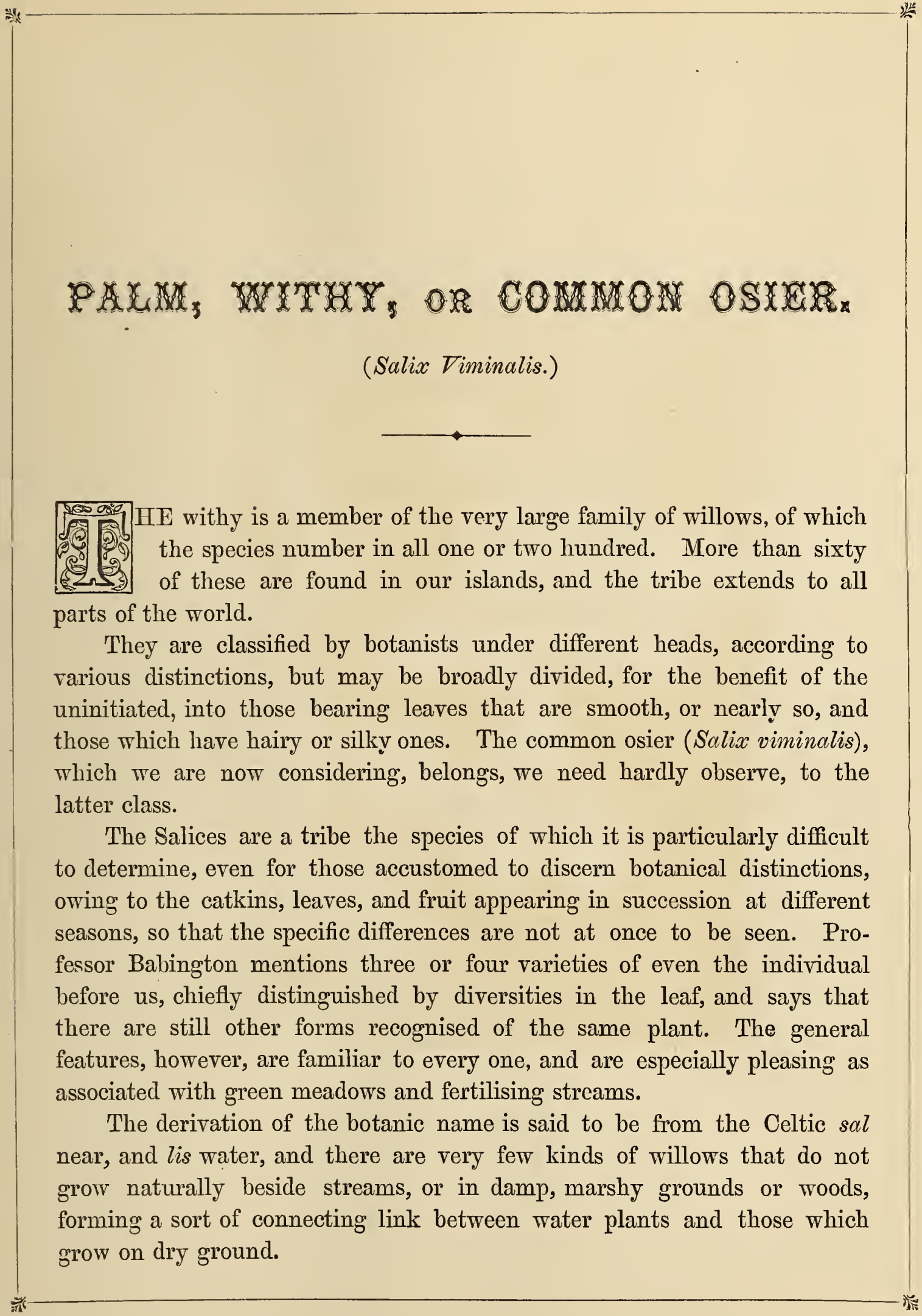


"They shall spring up as among the grass, as willows by the watercourses,"* is the simile employed by the prophet Isaiah in foretelling the increase and prosperity of the Church in the latter days; and the winding banks of a low, sunk river may sometimes be marked by its fringe of willows, when the water itself is not visible.

The withy, whose downy-looking catkins lie before us, is remarkable for its rather lance-shaped, slender, pointed leaves, somewhat crenate, as botanists call it, or waved, snow-white and silky underneath, and its straight, wand-like branches, downy when young. It grows from ten to twenty feet in height. Its name of osier is also significant of its growing near water, being derived "from a Celtic word meaning water, or ooze, that has given its name to the Oise in France, and to several rivers in England, spelt according to the dialect of the district, Ouse, Ose, Use, or Ise" (Prior). This willow has been in some places called likewise the palm, owing to the practice of carrying its boughs on Palm Sunday, as a substitute for the real palm, in commemoration of the incident in John xii. 13. $\dagger$

"Bearing the palm" was a mark of triumph and gladness, as we see also from Rev. vii. 9.

The willows are put to a great variety of economical purposes. Many are cultivated for making basket rods, the common osier amongst the number. It is also well adapted for hoops. Some species are used for stakes, poles, handles to gardening tools, \&c. In the north of Europe the bark of some kinds is used for tanning leather and dyeing yarn of a cinnamon colour, and the bitter principle of the willow bark is said to be an excellent substitute for quinine.

Like the beech, hazel, and many other trees, the willows bear the fertile and barren flowers separately, the latter being familiarly known as the "pussy cats," which, when fully ripe, shower their pollen so freely.

* Isaiah xliv. 4 .

† The common sallow (Salix Caprea) is also very commonly used in England, but we understand from good authority that different species of willows are chosen to represent the palm in Roman Catholic countries, and especially in the Greek Churches in Russia. The only reason that can be assigned for the choice of willows for this purpose seems to be that they flower about Easter, and the handsome catkins are a convenient substitute for the palm, owing to their quick growth and attractive appearance. 
The term "wearing the willow," as expressive of being forsaken, probably originates from the old English song-

\footnotetext{
"A poore soule sat sighing under a sicamore tree,

With his hand on his bosom, his head on his knee.

* ${ }^{*} *{ }^{*}$ * 0 the greene willow shall be my garland ;"
}

though why either the sycamore or the willow should be an emblem of despair is not apparent. "Willow, willow," was a favourite burden for songs in the sixteenth century (see Percy's Reliques of Ancient Poetry), but whether Shakspeare originated the song as it appears in "Othello," or whether it dates from a still older period, is uncertain. The idea cannot be derived from the weeping willow, as it was not known in England till the time of Pope. It is said that, having received a basket of figs in a present from Turkey, he observed one twig of the basket was putting out a shoot. He planted it, and it took root, and proved to be a weeping willow, from which stock all the weeping willows in England are descended. The name willow is supposed to have originated in the pliable disposition of the tree, the branches of which have always been so easily bent in basket-work, and various kinds of manufacture, from the Anglo-Saxon willig.

"I do not claim, like eastern palm,

With stately plume to rise,

Amid the desert's voiceless calm,

To gladden weary eyes.

"A lowlier but less lonely lot,

In English meadows born,

I grow in sweet companionship

With woodbine and may-thorn.

"And of the boughs triumphant wav'd,

In reverent memory borne,

My silky buds come shyly forth

To greet Palm Sunday morn."

The female humble bee is among the first of her kind who greets our 
ears with her welcome, familiar hum, telling us of the return of honeymaking days, when she and many of her race

"Cling to the bud, and with inserted tube

Seek its pure essence, its ethereal soul."

This bee (Bombus terrestris), probably the sole survivor of her large colony of last year, has just awoke from her winter sleep, and has begun her search after a suitable position for a new nest, where she may become the mother of hundreds, the progenitor of thousands of her race. These bees make their nests in the ground, and are at great pains to find a spot in loose, friable soil, where they can dig down to some depth, and excavate a small hole in which to form their first cells. The cells, unlike those of the hive bee, are very irregularly arranged, forming little groups of different sizes. The first groups produce the working bees, later in the season the males and females appear, the whole nest generally consisting of between 300 and 400 . The larvæ of the humble bee are large, fat, white grubs, with horny heads and curved bodies.

There is a difference of opinion as to the stinging propensities of this bee, but the general impression seems in favour of its harmlessness, whilst its beauty ingratiates it with most dwellers in the country. Its honey is remarkably sweet, both to taste and smell, but not very wholesome to eat.

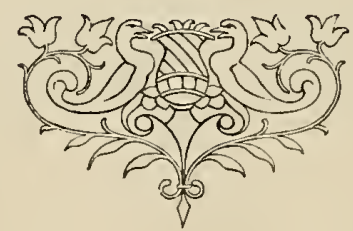





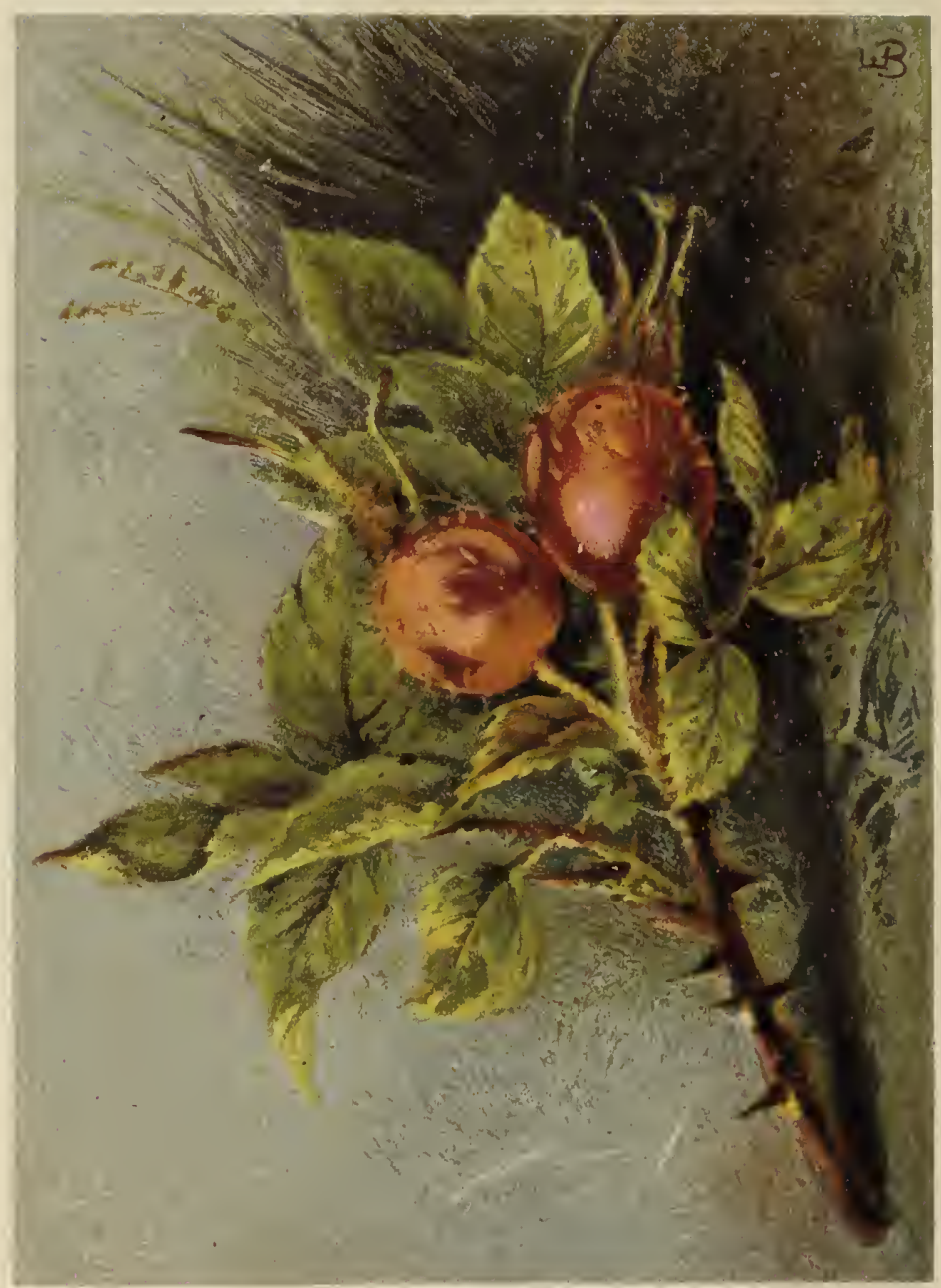




\title{
TORXSXXed
}

\author{
(Rosa Sabini.)
}

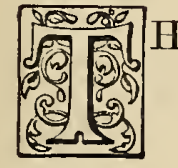

HESE hips represent one of the most beautiful varieties of our wild rose. The deep colour of its petals, compared to others of its kind, suggesting the idea that it must be the species that was best known in aneient times, the erimson hue of whieh gave rise to the myth that it sprang from the blood of Adonis. Gerarde ealls the wild rose indiseriminately, "the sweet briar, eglantine, or hep tree, and Rosa canina," but the latter is in point of faet a different speeies of the plant, of which there are not less than eighteen distinet kinds, and these again are subdivided into many varieties, which even botanists themselves find it difficult to determine.

Ordinary observers may easily be aware, lowever, that various specimens differ eonsiderably in marked eharaeteristies from one another. The common dog-rose, best known in England, the eglantine, or Rosa rubiginosa, and several more rare speeies, lave smooth stems, destitute of bristles, whilst others have their branches eovered with them. The Rosa sabini belongs to the latter elass. The hips are large and bright red, erowned with what are called long beards, and bristly'as well as the stems. This kind is frequent throughout the north of England and Scotland. In Yorkshire the common people eall the hips, chupes.

In some parts of the north it forms a most striking ornament to the country in the height of summer, the roadside hedges being almost lined with it, and other varieties, so that every shade of rose colour is presented, from the deepest pink to the most delieate blush, fading into white, answering well to Shakspeare's deseription-

\footnotetext{
"The roses fearfully on thorns did stand, One blushing shame, another white despair ;

A third, nor red, nor white, had stolen of both."
} 
Anything more delicately lovely and graceful than a nosegay of wild roses of these various shades can hardly be produced. If they are in their first budding so much the better, for it is most true-

\footnotetext{
"The rose that decks the woodland thorn, Is fairest in its opening blossom."
}

There is little doubt that the wild rose is the unassuming origin of all our garden beauties, and that it is a native of our own as well as of other lands. It has been justly remarked of the rose that "its beauty and fragrance have been the theme of poets, and lovers of nature, throughout all ages, and that it is by universal consent it has been acknowledged the queen of flowers."

The Romans used to strew roses over their streets during their public festivals, and the expression, " under the rose," may be traced to its having been the symbol of silence among the Egyptians, their god of silence, Harpocrates, being crowned with a wreath of its flowers. But to return to our illustration. Even in autumn, when most other trees and plants have lost their beauty, and there is little to be seen but brown stems and faded leaves, the wild rose can boast-

\footnotetext{
"Though of both leaf and flower bereft,

Some ornaments to me are left:

Rich store of scarlet hips are mine."
}

A store largely appreciated by many species of wild birds during the rigours of winter. Gerarde calls it the hep-tree, saying that "it were to small purpose to use many words in the description thereof, for even children with great delight eat the berries thereof when they be ripe; cooks and gentlewomen make tarts and such like dishes for pleasure thereof." And again: "The fruit when it is ripe maketh most pleasant meats and banqueting dishes, as tarts and such like, the making whereof I commit to the cunning cook, and teeth to eat them in the rich man's mouth."

This practice has very much gone out among ourselves, possibly from the comparative rarity of the species thus used. It is still a very common confection abroad, in some parts of Germany, where the hips are of a large and juicy kind. 
The cooking species that Gerarde knew may perhaps have been eradicated, as he mentions that they grew "very plentifully in a field as you go from a village in Essex called Graies, upon the bank of the river Thames, unto Hornden-on-the-hill, in so much that the field is full fraught with them all over." "It groweth likewise," he says, "as you goe from a village hard by London, called Knightsbridge, unto Fulham, a village thereby." The word hip, or hep, is traceable to the Anglo-Saxon hiop, Norw. hiupa and jupe, a corruption from the Latin jujuba, the $j$ having " become $h i$, as in many other instances, through the intermediate sound of $y$." The name jujuba was probably given to the wild rose as to many other prickly shrubs, and from the tree itself came to mean the fruit only. The wild rose is used in medicine, but principally as a vehicle or basis for more powerful remedies. It has been made into a preparation for coughs, with almonds, squills, and opium. The red rose, which has acquired the title of English rose, because it and the white rose are the most ancient of the cultivated kinds known here, is also used in medicine. According to Gerarde, Pliny affirms that the root of the briar bush is a singular remedy found out by oracle against the biting of a mad dog.

Our wild rose is but very slightly fragrant, some kinds having no scent at all. There are a few exceptions, as the sweet briar, and one or two white varieties, sufficient to justify the poet's description-

"The wild rose, eglantine, and broom,

Wasted around their rich perfume."

But their claim to admiration lies chiefly in their beauty and grace.

The name of rose is said to have sprung from the Celtic rhos, red. The more ancient name for the shrub was rubus, which is also expressive of a red colour.

The word eglantine has been the subject of much discussion, as to the shrub it was intended to designate, but probably the poets who used the term were not particular as to species, and only meant a rose of some kind. Dr. Prior tells us that in old French writers it signified the wild rose, and is said to be derived from the Latin aculeus, a prickle, through aculentus, hence, in old French, aiglent, covered with prickles, and aiglentier.

We cannot conclude our observations on the wild rose without 
alluding to the flowers of Towton Field, so well celebrated by Mr. Planché, in a poem entitled, "A Ballad of Battle Acre." Being on a visit at Grimston Park, he relates in his autobiography, he was present at an entertainment given by Lord Londesborough to his tcnantry. A large marquee was erected close to the traditional site of the decisive struggle between York and Lancaster, when the latter were beaten in the battle of Towton Field. In the course of the evening Mr. Planché became arare of the existence of the flowers of Towton, a quantity of wild white roses, which flourish in a particular part of the field, in spite of the attempts which have been made to uproot them by the farmers of the land. Lord Londesborough had endeavoured to preserve them since he came into possession of the property, and at the time of which Mr. Planche writes, 1858, they still made their annual appearance. Tradition states that they were planted by the victorious Yorkists on a spot where many of their slain had been buried, and to Mr. Planché the circumstance suggested the lines which seem an appropriate conclusion to a notice of English wild roses.

"There is a patch of wild white roses that bloom on a battle-field, Where the rival rose of Lancaster blushed redder still to yield;

Four hundred years have o'er them shed their sunshine and their snow, But, in spite of plough and harrow, every summer there they blow; Though rudely up to root them with hand profane you toil, The faithful flowers still fondly cluster round the sacred soil ; Though tenderly transplanted to the nearest garden gay, Nor cost nor care can tempt them there to live a single day.

"I ponder'd o'er their blossoms, and anon my busy brain With banner'd hosts and steel-clad knights repeopled all the plain. I seem'd to hear the lusty cheer of the bowmen bold of York, As they mark'd how well their cloth-yard shafts had done their bloody work. And steeds with empty saddles came rushing wildly by, And wounded warriors stagger'd past, or only turn'd to die, And the little sparkling river was cumber'd as of yore,

With ghastly corse of man and horse, and ran down red with gore.

"I started as I ponder'd, for loudly on mine ear Rose indeed a shout like thunder, a true old English cheer; And the sound of drums and trumpet came swelling up the vale, And blazon'd banners proudly flung their glories to the gale; 


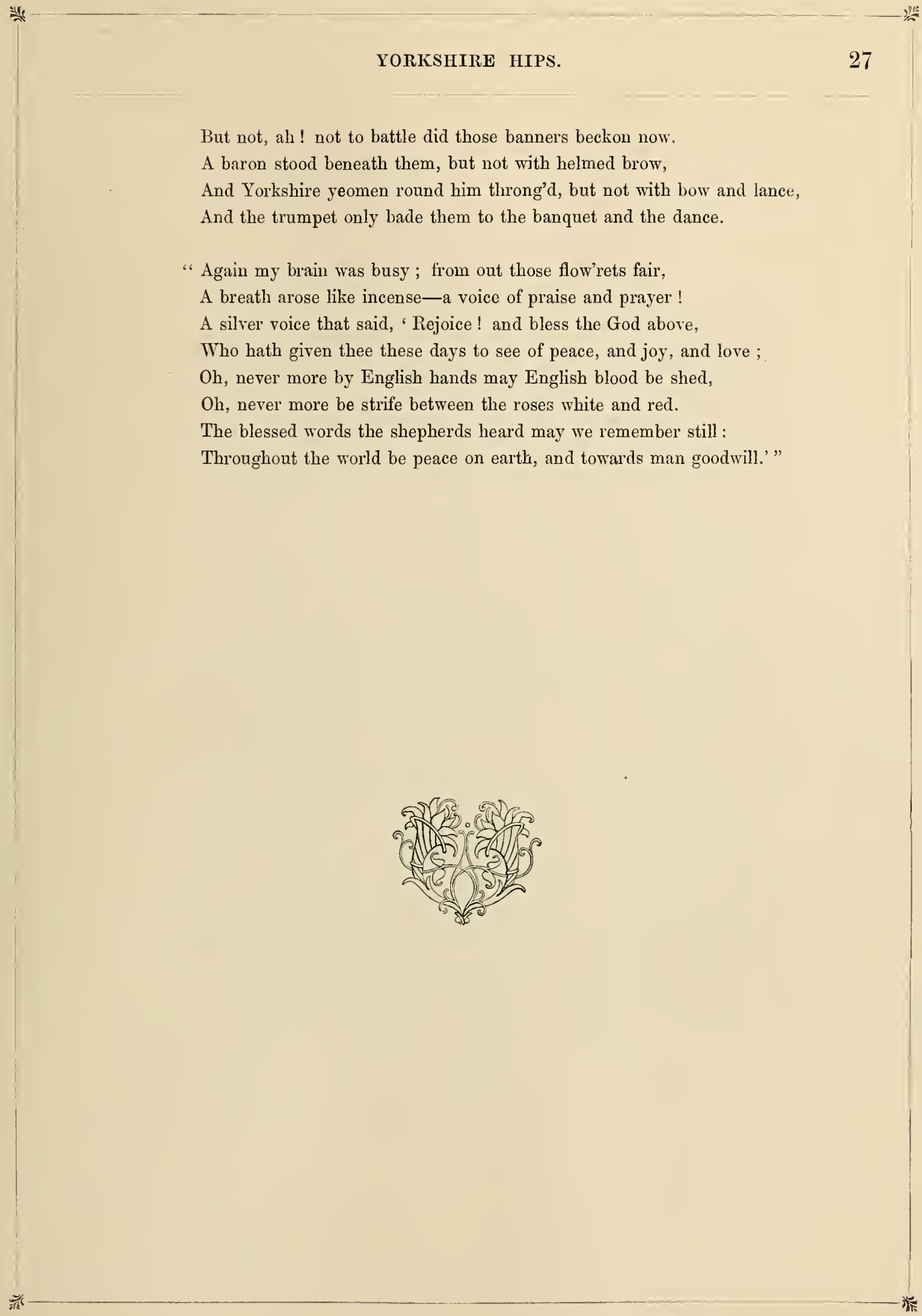




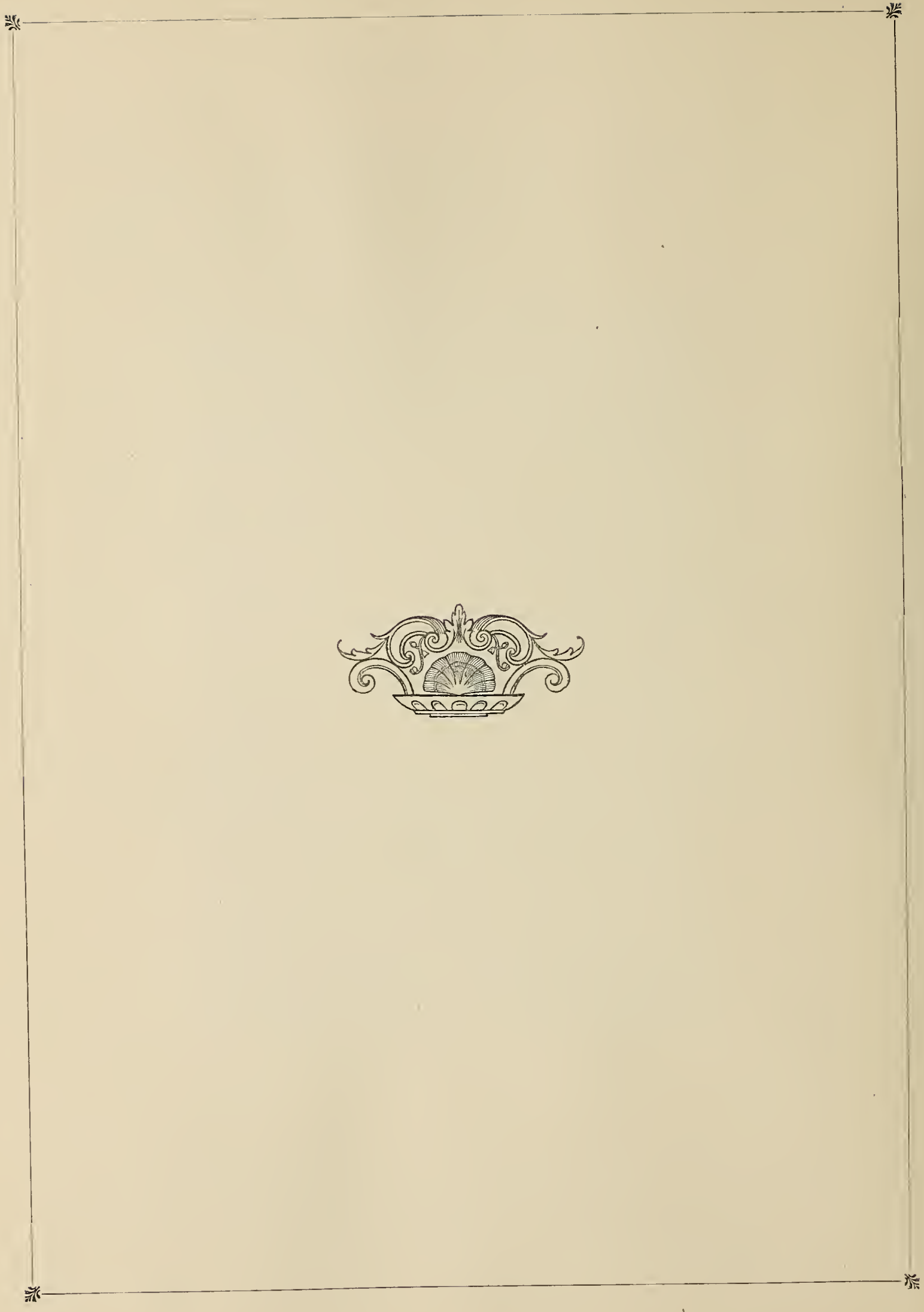





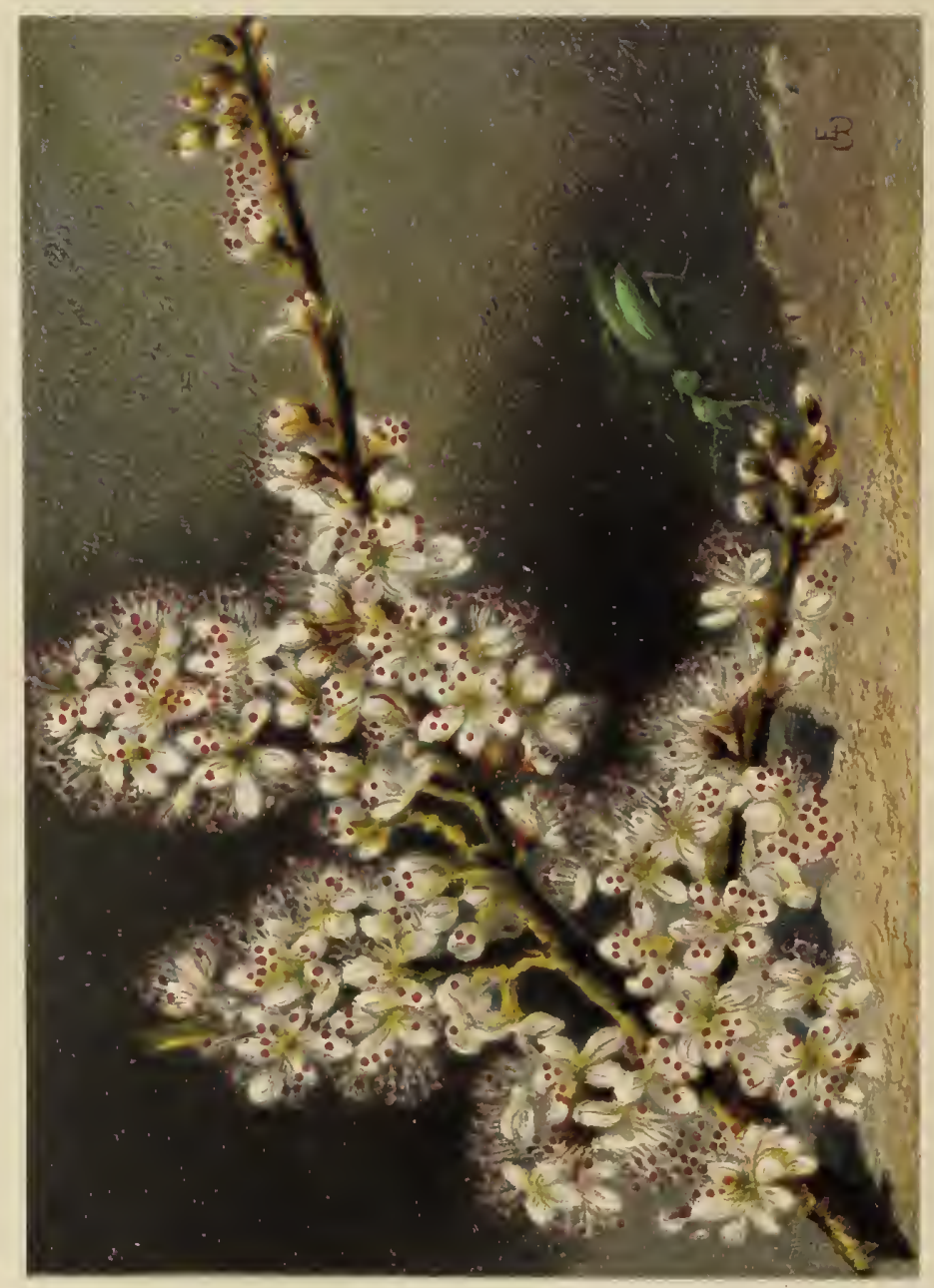




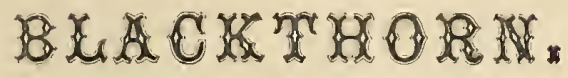

(Prunus Spinosa.)

HE blackthorn or sloe-tree, so called from the blackness of its rind at the time of flowering, in contrast to the white or hawthorn proper, is pleasing, as associated with the time when

$$
\begin{aligned}
& \text { "Smiling Spring comes in rejoicing, } \\
& \text { And surly Winter grimly flies." }
\end{aligned}
$$

This progress, however, is so frequently reversed, simultaneously with the flowering of the tree, as to have acquired the name of the "blackthorn winter," from the cold weather that often recurs in March or April, dissipating the fond delusion, so common to inexperienced youth, that the "budding thorn" portends the approach of spring or summer.

There is no doubt, however, of the remarkable beauty of its pure white blossoms, which, from being very numerous and thickly clustered on the branches, appear at a little distance like small masses of snow. It is a species of the wild cherry or gean-tree, to which it is very inferior in the nature of its fruit, and is distinguished by a strong thorn at the end of each branch, which makes it valuable in the formation of hedges on account of its defensive properties; likewise it seems much coveted as a residence by thrushes, blackbirds, \&c., whose early building habits demand a position well screened from observation.

Professor Balfour, in his work on the structure of plants, entitled Phyto-Theology, tells us that thorns are in rcality undeveloped branches, and under cultivation become frequently true branches. Branches are produced in the form of buds connected with the centre of the woody stem, and have the same structure as the stem from which they spring. But, owing to various causes, it is seldom that all the buds are properly developed. 
Many lie dormant and do not appear at all, others, after increasing to a certain extent, die and leave knots in the stem, and others are altered into thorns.

Thorns such as are in the sloe-tree and hawthorn are different from the prickles on the rose. These are connected only with the surface of the plant, and are an altered condition of the hairs which become hardened. This circumstance, Professor Balfour remarks, seems to throw light on Gen. iii. 17, 18, as if a blight had passed over certain parts of creation, as a standing memorial of the effects of sin on what was at first declared to be very good. The great prevalence of thorny shrubs throughout the countries of the East is very notorious.

The thorn can vie, with most trees in its capability of attaining a great age, and many remarkable spots might be pointed out on which the landmark is an "aged thorn."

\section{"There is a thorn, it looks so old, In truth you'd find it hard to say How it could ever have been young, It looks so old and grey."}

WORDSWORTH.

The Glastonbury Thorn, though not belonging to the same family, is an example of this tenacity of life in the species. If it had not been ruthlessly cut down in the Great Rebellion, it might still have represented the staff of Joseph of Arimathea, and scions of its stock are yet in existence.

Another tree of this kind, whose venerable trunk was to be seen a few years ago, if it is not now remaining, stood in the centre of Cawdor Castle, Nairnshire. Tradition states that it grew there before the castle was built, and consequently before even Macbeth became Thane of Cawdor. The legend is, that the original possessor of the land being in doubt as to the spot on which to build, allowed an ass laden with two bags of gold to take its own course, resolving to choose the site at which it paused. This proved to be the thorn, which was therefore made the centre of the building. However mythical these legends may be, they bear witness to the antiquity of the trees.

The musk beetle (Ceramby $x$ moschatus), painted beside our blackthorn 
blossom, is a very beautiful and not at all rare specimen of the innumerable insects of that class that abound among us. It receives its name from its power of emitting a scent, supposed to resemble that of musk, which is so strong that some say the insect may be discovered by it.

Its rich green and purplish blue dress rank it among the most conspicuous of its class, so many of which are remarkable for the beautiful colour of their elytra or upper pair of sheath-like wings, under which the binder pair, transparent and membranous, are folded as in a horny case.

Though so brilliant, the colour of the musk beetle is in such harmony with the leaves on which it lies, that it may easily be overlooked, but its long graceful antennæ, gently waving, discover it to experienced observers.

Mr. Wood (Homes without Hands) says of this beetle-

"To the naked eye, and in an ordinary light, the colour of this beetle is simply green, very much like that of the malachite. But when the sun shines on its elytra, some indications of its true beauty present themselves, not to be fully realised without the aid of the microscope and careful illumination."

Thus viewed, "the true glories of this magnificent insect become visible. The general colour is green, but few can describe the countless shades of green, gold, and azure that are brought out by the microscope, and no pencil can hope to give more than a faint and dull idea of the wonderful object. Neither do its beauties end with its colours, for the whole structure of the insect is full of wonders, and, from the compound eyes to the brush-soled feet, it affords a series of objects to the microscopist which will keep him employed for many an hour."

The larva of the musk beetle is a long white grub, found chiefly in decaying willow-trees, in which it makes its burrows for the purpose of passing through its pupal state.

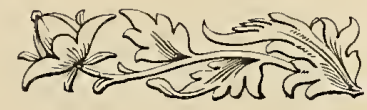




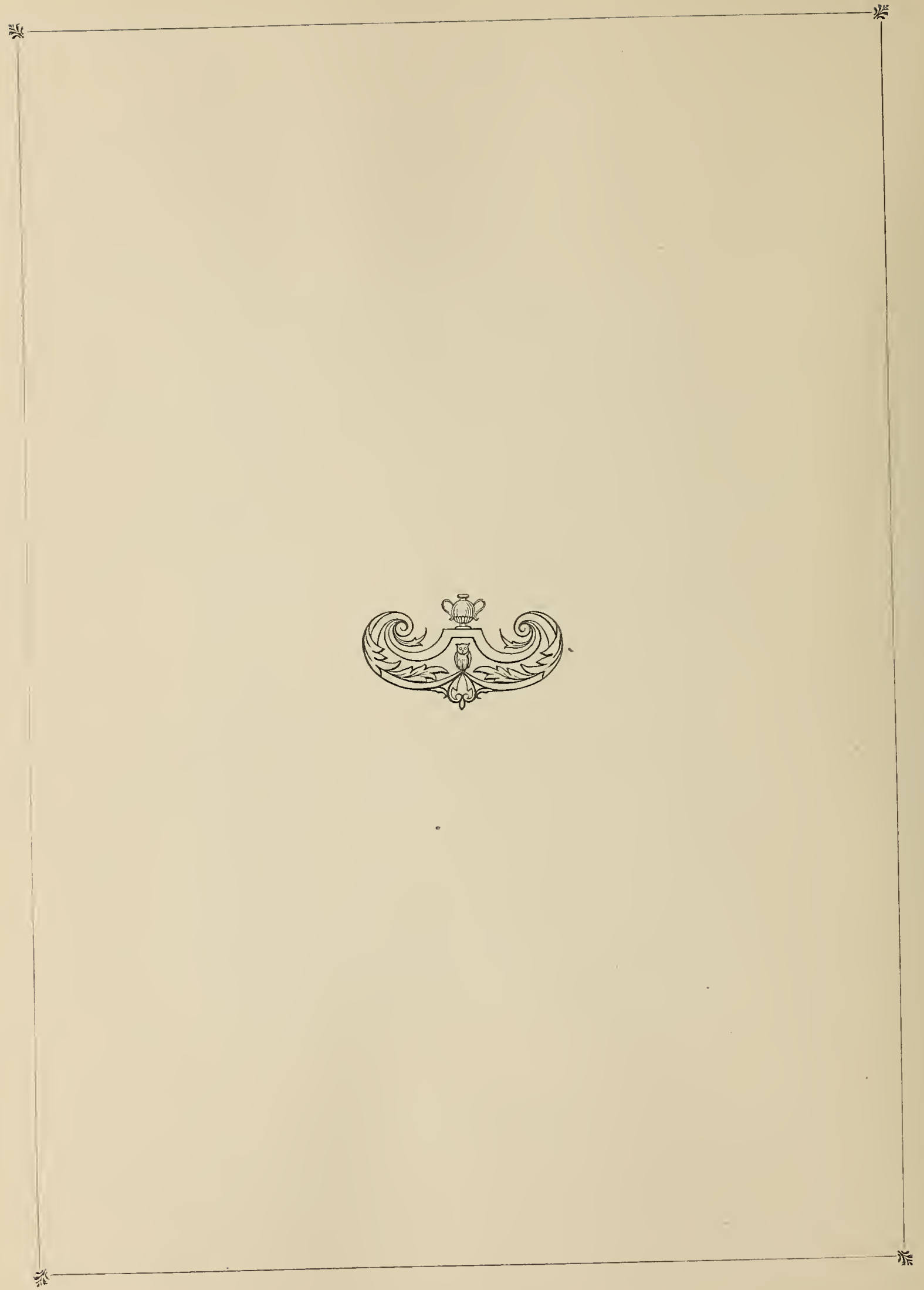


• 


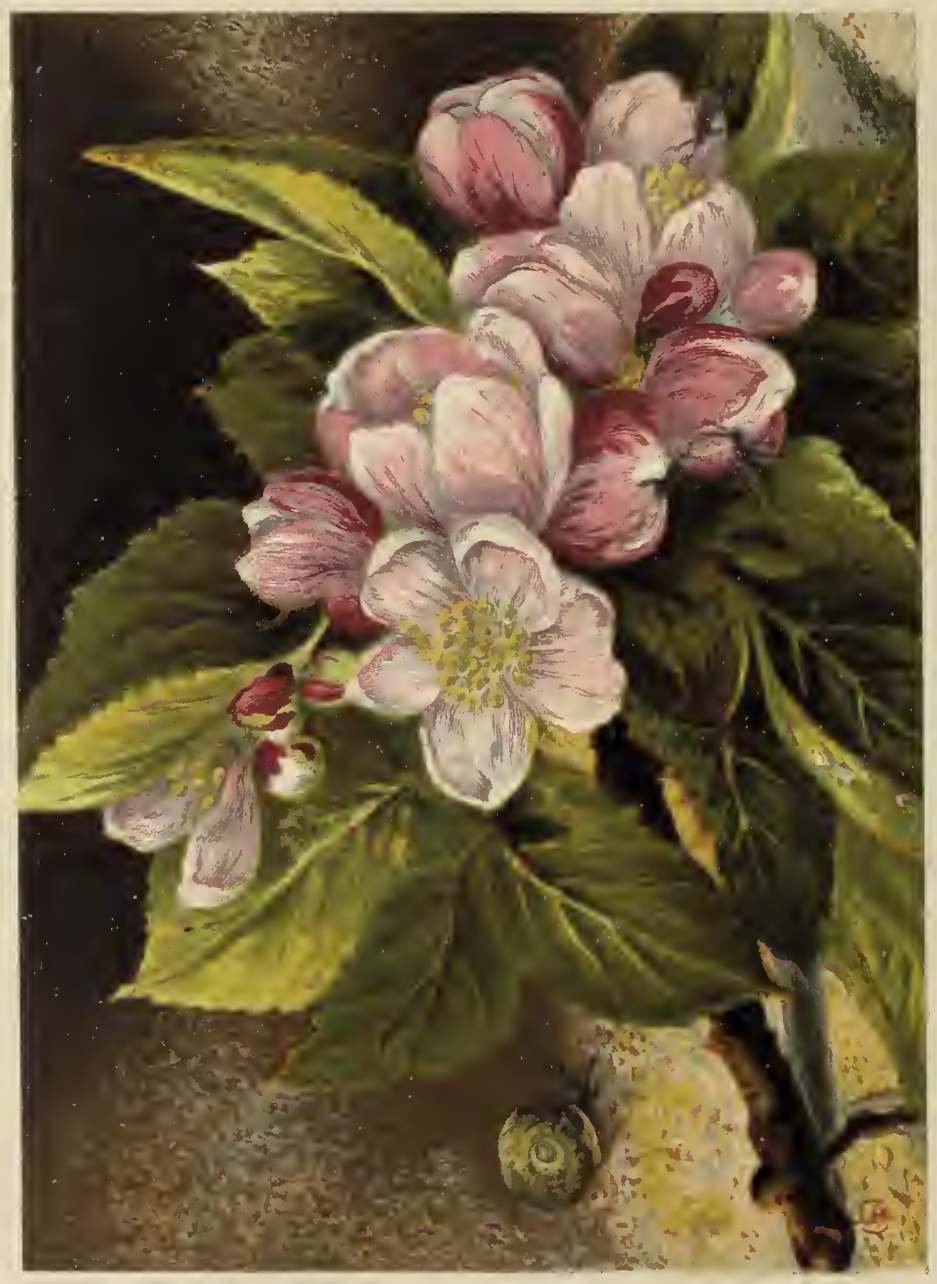




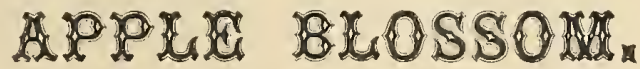

\section{(Pyrus.)}

"Then they brought them up a dish of apples, and they were a very good tasted fruit.

"Then said Matthew, "May we eat apples, since they were such by and with which the serpent beguiled our first mother?'

"Then said Gaius-

" 'Apples were they with which we were beguil'd,

Yet sin, not apples, hath our souls defil'd.',

Pilgrim's Progress.

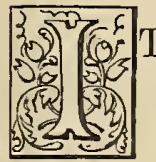

I might seem as if Nature had resolved to compensate the appletree for the odium attached to it of having been the unconscious instrument of man's greatest calamity (the fact of its being identical with the forbidden fruit is, we must observe, however, of very doubtful truth) by bestowing on it beauty, popularity, and usefulness combined, to a greater degree than on any other fruit-bearing tree. The loveliness and fragrance of the universal burst of apple blossom in an orchard country is well-known, when-

"At once array'd

In all the colours of the flushing year,

By Nature's swift and secret working hand,

The garden glows and fills the liberal air

With lavish fragrance; while the promis'd fruit

Lies yet a little embryo unperceiv'd

Within its crimson folds."

And we-

"See the country far diffus'd around,

One boundless blush, one white empurpled shower

of mingled blossoms."

According to Dr. Prior, to whose interesting work on the nomenclature of British plants we are indebted for the origin of the names of most of the flowers we have described, the garden, or eatable, apple is not, as has been 
generally supposed, the cultivated descendant of Pyrus malus, the crabapple, but the latter the degenerate offspring of the former. Owing to the similarity of the name, allowing for dialect, among all the Celtic and Sclavonic languages, he believes that it was "brought with the tree from some one country, and that, no doubt, an eastern one;" that it "accompanied our ancestors on a northern route from the westcrn spur of the Himalayan Mountains, a district extending through ancient Bactria, Northern Persia, and Asia Minor, to the Caucasus," one "in which there is reason to think our portion of the human race first attained to civilisation, and whence it spread with its domestic animals and plants to the southeast and north-west." "The meaning of the word is unknown : it is very possibly from the Sanskrit, amb, eat, and $p$ 'hal fruit; but as ap is, in Zend and Sanskrit, 'water,' we might be tempted to believe that it originally meant 'water fruit,' with which the Latin pomum, from po, to drink, exactly tallies" (Popular Names of British Plants).

Notwithstanding its eastern origin, to which is owing, possibly, the long established idea that it represents " the tree of the knowledge of good and evil," it is more than doubtful whether the fruit alluded to in various parts of Scripture is rightly translated the apple in our version. Dr. Tristram, in his Natural History of the Bible, says, that although it is cultivated with success in the highest parts of Lebanon, out of the boundaries of the Holy Land, yet it barely exists in the country itself. The tree which best suits the description in the Bible hitherto attributed to the apple, in point of beauty, sweetness, fragrance, and yielding an agreeable shade, is, in his opinion, the apricot.

It would be difficult to arrive at a proximate idea of the varieties of the cultivated apple. In an edition of Abercrombie's Gardeners' Calendar, published the beginning of this century, a select list of fifty-eight is given, and probably they now amount to hundreds.

The use of the apple as a wholesome and agreeable fruit is universal, and the various modes of treatment it receives amongst ourselves, and far more from our friends across the Atlantic, are almost innumerable. Varieties of the fruit arrive at their full growth in successive order from July to October, and many of them improve by keeping. Several winter kinds keep good for many months, till the next year's crop; but the time required in cooking them varies according to that which has elapsed since 
the apples were pulled, the mellower ones being of eourse more quiekly eooked; henee the enigmatical direction that appears in some cookerybooks in a recipe for apple pudding:- "If before Christmas, boil so many hours, if after-so many."

Apples may be divided into tluree sorts, eating, eooking, and eider apples. Cider making, as is well known, is an important operation in orehard eounties, in the south and west of England; Devonshire and Woreestershire being the prineipal. The apples are left in heaps in an open part of the orehard, for a time varying from a fortnight to six weeks, aeeording to their ripeness when pulled, the more mellow requiring a shorter time to prepare. They are then ground and put into an open vessel to "break," as it is termed, almost immediately after whieh the pulp is pressed. If this is not done the same day that it "breaks," it ferments, and turns to vinegar. There is a spirituous liquor ealled "eider spirit," drawn from eider by distillation, as brandy from wine, whieh is often used for purposes of adulteration. The odour of the sweet apple was in old times considered healthful in eertain diseases, and Gerarde mentions an ointment in use in lis time of the pulp of apples, lard, and rose-water, which was ealled pomatum from pomum, whieh beautified the skin.

To eat an apple before the looking-glass, alone, holding a eandle in the other hand, was one of the spells in use on Hallowe'en.

We need hardly allude to the ravages made in orehards by the inseet world. The

$$
\text { "Busy, envious, thirsty fly," }
$$

with its swift flight and wondrous powers of vision, is perhaps the most larmless of their visitants. The snail, though it ean exist a long time witlout sustenanee, many months and even years, ${ }^{*}$ eommits great depredations when it sets to work; its eight small teeth being capable of biting substances seemingly harder than any part of its own body. The little snail whieh is finding its reereation beside our apple blossom is a speeimen, youthful, probably, of the Kentish snail, Helix Cantiana, one of the same type as the little white snail, Helix pulchella, although the eolour of the shell often varies in members of the same type.

* In Bingley's Animal Bioyraphy, a very authentic instance is given of snails reappearing from the recesses of their shells on being plunged into water, after having lain in a cabinet of curiosities more than fifteen jears. 
Apple-trees have been known to attain a very large growth. Sir T. Dick Lauder mentions that one growing in a garden at Jedburgh, in 1763, measured, at three feet above the ground, seven feet two inches. The spread of its branches was above forty feet in diameter, and it bore eight holls* of apples.

* The boll contains ten stone, Scotch measure.

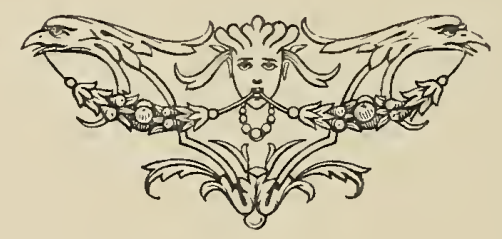




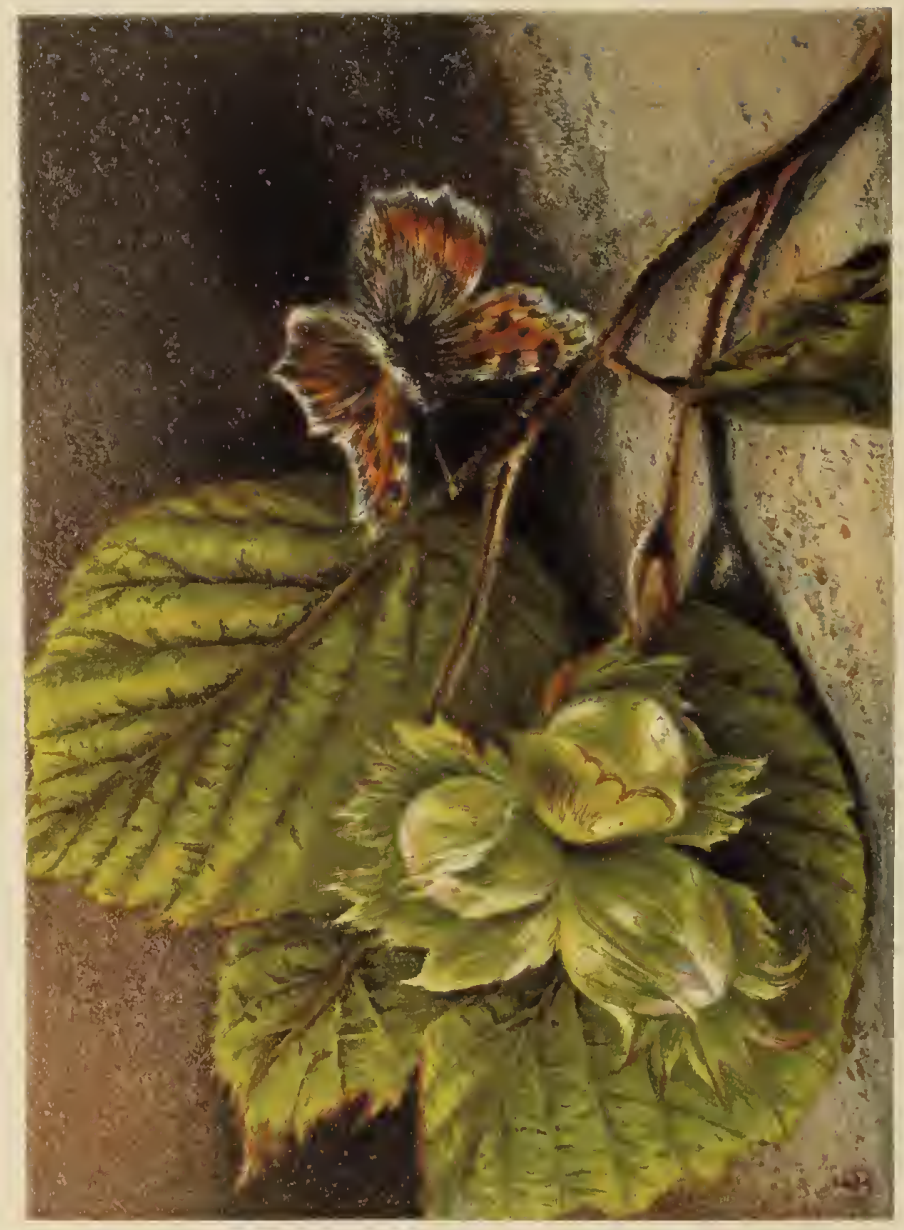




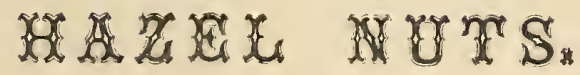

(Corylus Avellana.)

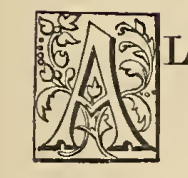

LTHOUGH but a small, bushy tree, the importance of the hazel as a feature in woodland scenery is fully acknowledged. Filling up spaces in the sides of ravines, or in the heart of groves and copses, with its long, slender branches, of many a romantic defile, besides the Trosachs, may it be said-

"Hawthorn and hazel mingle there;"

and of many a clamberer besides Fitz-James,

"The broom's tough roots his ladder made,

The hazel saplings lent their aid."

In spring its young, hairy stems, bearing their long, pendulous catkins and crimson stigmas, are among the first gladly recognised tokens of reviving vegetation; and the poet of the Seasons speaks of its branches as affording shelter to the early-building birds-

"Among the rows of hazel pendant o'er the plaintive stream,

They frame the first foundation of their domes."

But perhaps it is from its well-known nuts that the hazel has chiefly won its popularity, the human predilection for which is shared by squirrels, mice, jays, nut-hatches, and-truth necessitates our adding-pigs. There are few of us who cannot look back with a glow of tender recollection to days passed in woods and coppices.

"One of those heavenly days that cannot die,

When in the eagerness of boyish hope

I left our cottage threshold, sallying forth

With a huge wallet o'er my shoulder slung,

A nutting crook in hand, and turned my steps

'Tow'rd some far distant wood. 


\section{"Through beds of matted fern and tangled thickets \\ Forcing my way, I came to one dear nook \\ Unvisited, where not a broken bough \\ Droop'd with its wither'd leaves, ungracious sign \\ Of devastation; but the hazels rose \\ Tall and erect, with tempting clusters hung,- \\ A virgin scene."-WoRDsworth.}

"The root of the hazel," as Gerarde expresses it, " is thick, strong, and growing deep, and instead of floures, hang down catkins, aglets, or blowings, slender and well compact, after which come the nuts standing in a tough cup of a grcen colour, and jagged at the upper end like unto the beards in roses. The catkins or aglets come forth very timely, before winter be fully past, and fall away in March or April so soon as the leaves come forth."

This timely coming forth of the catkins is one of the many proofs of design in the careful and beautiful provision of Nature for the proper fructifying of the pistil. The hazel is one of those plants which bear the pollen in one set of flowers, the pistil in another. The pollen is communicated to the pistil by the action of the wind, and as this might be intercepted by the leaves, if they appeared before the process is completed, their production is delayed.

An oil, not inferior to that of almonds, is extracted from the hazel nut, which is used by painters and chemists, in order to receive and retain odours, and charcoal made of the wood is employed by painters in drawing. A substance, not unlike chocolate, has also been made from the nuts, and even bread.

Evelyn says no plant is more proper for thickening copses. It will prosper in almost any soil, and can be turned to good account when growing in coppices, as it may be cut as underwood, and, from its toughness, forms good poles for sticks, fishing-rods, \&c. It is best propagated by layers, but it may be raised from the nut.

The hazel is regarded in the Highlands of Scotland with some degree of superstition. It is scarcely looked upon as unlucky, but as an object not to be trifled with. "Two nuts in one shell are considered a good omen, and a charm against witchcraft. Such a nut is called cno-chomblaich, a "two in one nut." Probably the French custom of presenting a double nut in connection with the phrase "Bon jour, Philippine," owes its origin to the same idea. Possibly the veneration for the hazcl may have arisen from the 
fact that the hazel wand was, amongst Germanic nations, a symbol of authority. Dr. Prior tclls us that " the name is derived from the old German haizan, modern heissen, to give orders, a lazel stick having been used to enforce orders among slaves and cattle, and been the baton of the master." The verb haelsian, forctell, on the other hand, seems "derived from the use of the hazel rod for purposes of divination."

It was also employed for discovering veins of ore, in which character" it was known in the West of England as the "dowsing rod;" and we need scarcely allude to the practice of burning hazel nuts on Hallowe'en, when-

"Some kindle couthie* side by side,

And burn thegither trimly;

Some start awa wi' saucy pride, And jump out owre the chimlie

Fu' high that night."

The custom probably originated in the supposed power of indicating the future attributed to the tree.

"In copse and dingle, brae and glen, With birch and fern and rose,

With charm and spell by all lov'd well,

The happy hazel grows.

"In chilly dawn of earliest spring, Ere buds or leaves have birth,

We watch its tassels gentle swing,

It shares our winter mirth.

" Of old, enchanters sought its aid,

Earth's hidden wealth to see;

And magic wand in wizard hand

Of hazel bough must be.

"And merry maidens fond believe,

That in the nut-brown shell

There lurks a power on Hallowe'en, Of happy homes to tell.

"And well I trow can nut or bough

Wise secrets still unfold,

Of witching charms, as potent now

As in those times of old.

* Pleasantly. 
"A gentle grace, a modest mien,

A heart that must be sought;

By these the parent ore is seen, And lasting spells are wrought."

The bright-winged creature represented beside our cluster of nuts, not less wonderful because it is a common object, is the butterfly known as the lesscr tortoise-shell, Tanessa urtica. It is found very plentifully in evcry country district. Like others of its bright-coloured genus, it feeds in its caterpillar state on the stinging-nettle, on which numbcrs may be found together. The caterpillar is of a grcyish colour, with a black stripe down the back, and brown and yellow stripes on the side. Occasionally, specimens of this butterfly may be seen early in spring, and remarkable instances are mentioned of flocks of them having been captured even in winter, in unusually mild weather; but these are individuals that have survived from the previous scason in a state of hybernation. The natural time for its appearance is the month of June, when the chrysalis undergoes its second birth, and assists with many millions of its kind to perpetuate that emblem of the resurrection which led the ancient Greeks to call the doctrine "the hope of worms," and to make the name of Psyche, the human soul or principlc of life, synonymous with that for a butterfly.

It would take up too much of our space to trace out fully the analogy between the various stages of the insect's growth and the soul's progress to a higher life. It is well hinted at in the popular prose poem of The Story without an End, in which the butterfly rclates, that "once on a time he had been greedy and sordid, had thought of nothing but eating, and ncver once turned his eyes upwards to the blue heavens. At length, howevcr, a complete cliange had come over him, and instead of crawling spiritless about the dirty earth, half dreaming, he all at once awaked as out of a deep sleep. And now he would rise into the air; and it was his greatest joy, sometimes to play with the light and reflect the heavens in the bright eyes of his wings, sometimes to listen to the soft language of the flowers, and catch their secrets."

If no other end is answered by the existence of these gorgeous insects than presenting us with so striking a picture of our everlasting hope, and the standing rebuke to scepticism it affords, they cannot be said to be a merely ornamental part of creation. 
The lesser tortoise-shell butterfly is distinguished from the large tortoise-shell, Vannessa polychlorus, chiefly by a pure white spot on the front wing next the blue and black border, and it has more distinct blue markings along the edge of the same wing, which in the large tortoise-shell are almost confined to the hind wings.

"I've watch'd you now a full half-hour Self-poised upon that yellow flower;

And, little butterfly! indeed

I know not if you sleep or feed.

How motionless! not frozen seas

More motionless ! and then

What joy awaits you when the breeze

Hath found you out among the trees, And calls you forth again.

"This plot of orchard ground is ours, My trees they are, my sister's flowers.

Here rest your wings when they are weary,

Here lodge as in a sanctuary ;

Come often to us, fear no wrong,

Sit near us on the bough;

We 'll talk of sunshine and of song,

And summer days when we were young,-

Sweet childish days, that were as long

As twenty days are now."

WORDSWORTH.

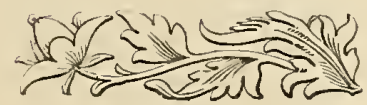




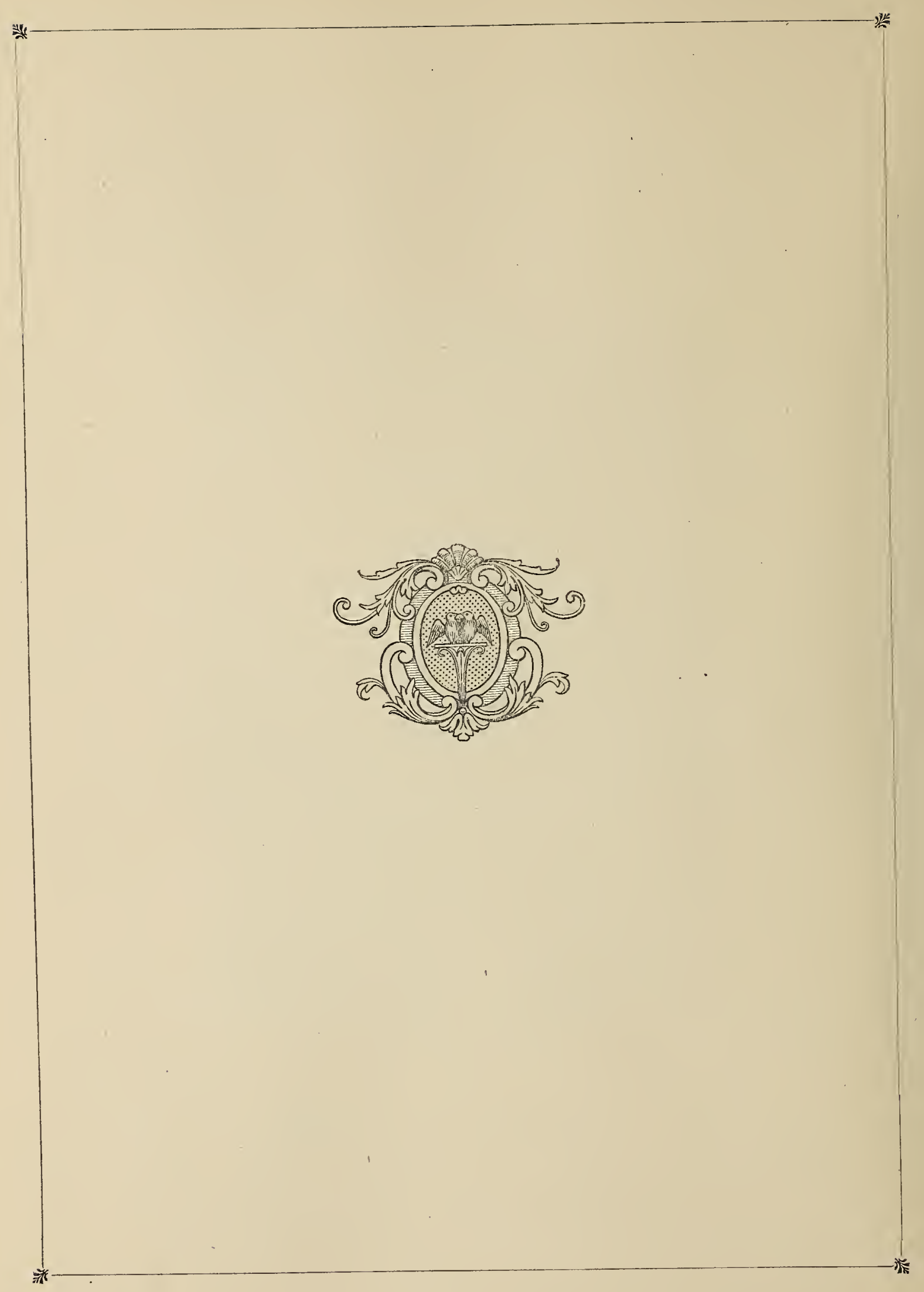





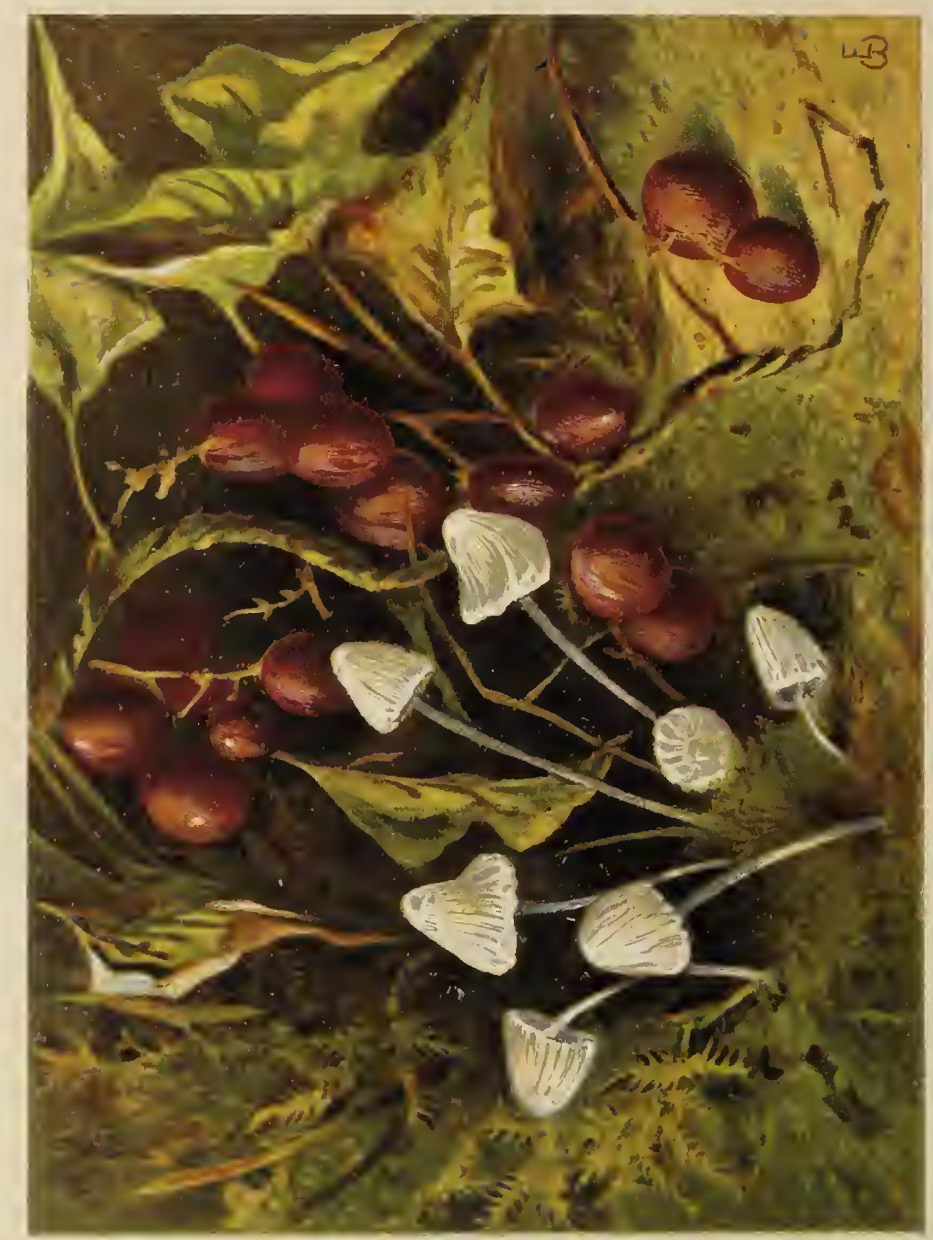




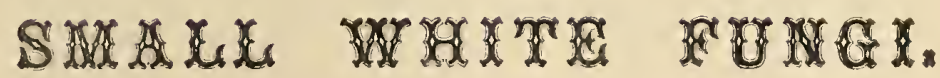

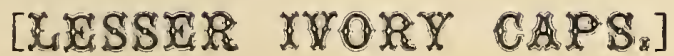

\section{(Hygrophorus Niveus.)}

to that large class of doubtful reputation popularly known as
toadstools.

It cannot be denied that this section of the regetable world has met with neglect from many students of botany, especially amateurs, much to the indignation of those who have made more intimate acquaintance witl these strange growths, - a neglect which seems to arise from a spontaneous and sumewhat natural repulsion to the order. Justly or unjustly, all fungi are looked on as unattractive to both sight and smell, and whilst we would protest against the wholesale conclusion as the result of prejudiced ignorance, it must be allowed that their origin scarcely recommends them at first sight.

"Wherever decaying vegetable matter exists," there is the paradise of fungi. "Every rotten stump or twig, every decaying leaf or fruit, has its peculiar species, some large enough to attract immediate attention, others so small as to be invisible to the unaided eye" (Cooke's British Fungi).

From the cnormous Polyporus, which has been known to attain a growth of more than seven feet in circumference, and to weigh forty-two pounds, down to the blue mould on a forgotten crust, or the mildew that destroys our wheat, or even the microscopic floating particles arising from impurity of air, all lay claim to the same parentage. Another suspicious fact regarding fungi is, that while "in flowering plants light is absolutely essential, not only to the healthy condition of the plant, but also to the production of the green chlorophyl or colouring mattcr, fungi, on the contrary, would appear to flourish best in the absence of light-in dark 
cellars, under flagstones, in hollow trees, and in like places where no other form of plant could exist, while some genera are entirely subterranean" (Cooke).

It is not wonderful that these peculiarities have rendered them unattractive to the world in general, and that they have become associated with darkness and decay. Yet we must not shut our eyes to the wonders of their composition. Many of the race arc large and unsightly in appearance, yet a closer examination would excite admiration, when we consider the intricate yet systematic arrangement of their gills and fructifying spores, which cannot be thoroughly appreciated without the aid of the microscope, whilst it is not difficult to yield a due meed of homage to such little fairy-like specimens as the group before us.

"Beauty hideth everywhere, that Reason's child may seek her,

And having found the gem of price may set it in God's crown."

That gem in the present instance takes the form of the attributes of power and wisdom which, even in this humble rank of creation, are true to the law illustrated in the most weighty affairs of the world, and cause life and beauty to spring out of decay and death-

"From seeming evil, still deducing good."

The little ivory caps which have given rise to these remarks are of a beautiful snowy whiteness when in good condition, but become dingy and tawny when fading. They are frequently to be found in little groups, on downs and pastures and in woods, and are said to be amongst the csculent fungi, although so small and insignificant that they appear scarcely worth cooking at all. The species can hardly be distinguished from another, Hygrophorus virgineus, which, however, is slightly larger.

Opinions differ strongly on the subject of the wholesomencss of many kinds of fungi.

Mycologists regard the widespread reluctance to partake of them as the result of the most perverse ignorance, and it is doubtless true that many more species might with safety be eaten than are now used as food. We are told on good authority, that " instead of the one or two species which appear in our markets in the autumn, there are upwards of fifty which 
might be easily discriminated from the noxious kinds, and the majority of which are fully equal, and some perhaps superior, to any of the kinds popularly considered esculent" (Cooke).

Still, setting aside the fact that, as in the case of honey, what may safely be eaten by some persons, proves injurious to others of a different constitution,-in other words, "one man's meat is another man's poison,"the general repugnance is, to say the least, excusable, when we consicler the experience and power of discrimination required in selecting the wholesome kinds : above all, what is admitted even by the advocates of edible fungi, that their harmlessness depends greatly on the conditions under" which they grow, and that it varies with different stages of their existence, "a few hours being sufficient, in some cases, to convert a wholesome food into a very injurious and perhaps dangerous substance."

The deep-rooted suspicion of these plants is betrayed, as we believe, in the name of "toadstool." It has been thought from very early times that it sprang from a popular belief that they were used by toads as a kind of throne to keep themselves from immediate contact with the damp ground on which they were unfortunatcly compelled to rest. This idea was endorsed by Spenser-

"The griesly todestool grown there mought I see, And loathed paddocks lording on the same."

But a much more intelligible origin has been assigned to it by Mr. Cooke, namely, the German Todstuhl, the stool or seat of death, from the impression that it was death to partake of it. 


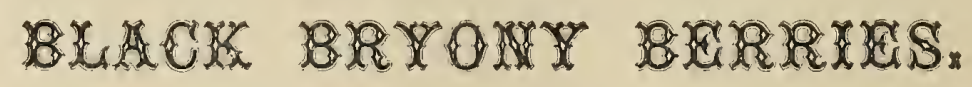

\author{
(Tamus Communis.)
}

HE beautiful but poisonous scarlet berries of the black bryony are a rich ornament to many an old woodland trunk in autumn, which feels about its feet

"The berried bryony fold."

Its long twining stems rise about them sometimes to the height of fifteen feet.

Its flowers are greenish white and insignificant, but its long tough stalks and green glossy leaves are very graceful. It is called the black bryony from the black colour of its large fleshy root, the inside of which is a whitish pulp, very acrid in its nature, and full of a slimy juice. The red, or white bryony, on the other hand, is white and rough.

The two species may easily be distinguished by the leaf-that of the black bryony being smootl, whole, and heart-shaped; the red, large, rough, and five-lobed.

Both plants have strong medicinal qualities, properly used, but are dangerous if applied incautiously. The root of black bryony is said by some to be the celebrated mandrake, and has been believed to possess wonderful properties. The young spring shoots are very mild, and when dressed as asparagus are, we are told, pleasant to the taste, but the poisonous nature of the plant makes it an undesirable indulgence. They are, however, eaten in Morocco when boiled, accompanied with oil and salt. Possibly the difference in the climate may cause some modification in their nature. 


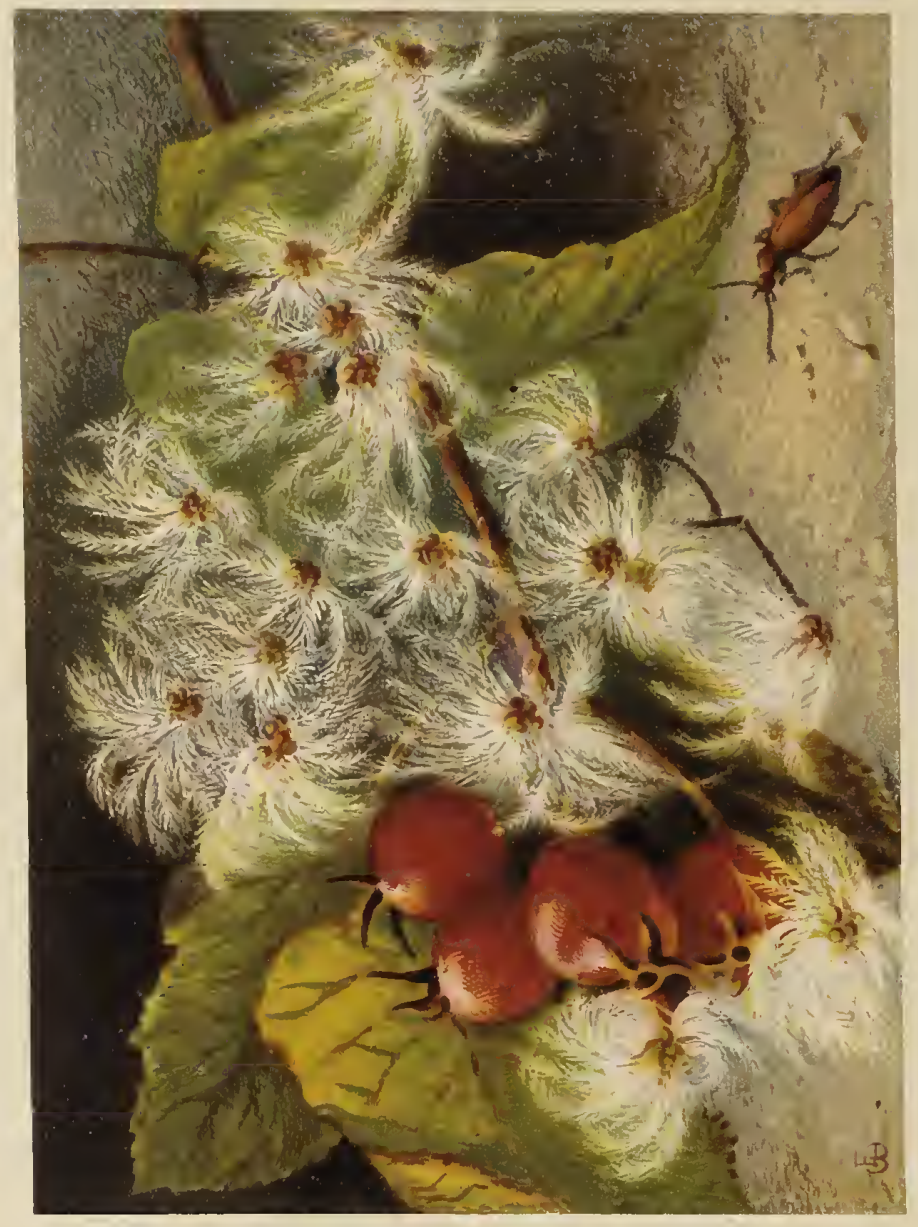




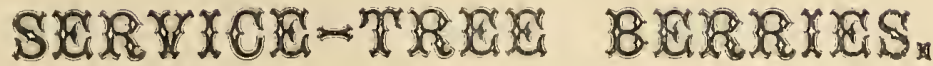

(Pyrus Domestica.)

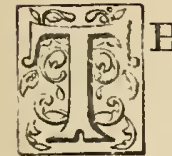

HIS species of service-tree is a native of the south of Europe, domesticated in Great Britain. It is closely allied to the mountain ash or rowan-tree, and also to the crab apple: all belonging to the family pyrus, or pear tribe. "It groweth," says Gerarde, "to the height and bigness of a great tree, charged with many great armes or boughs, which are set with sundry small branches, garnished with many great leaves, somewhat long like those of the ash."

The flowcrs are cream-coloured, the fruit egg-shaped and reddish; the latter is not unpleasant to eat if it is left to become soft, like the medlar, which it somewhat resembles in taste, and is therefore ranked in old gardening books among trees cultivated for their fruit. It is cared for and cherished also as an ornamental tree. Though not so bright and gracefullooking as its first cousin, the rowan, still it is welcome as contributing its share to the enlivenment of woods and fields-

"When winter winds are piercing chill, And through the hawthorn blows the gale."

Although not in any way botanically related to the ash, the slight rcsemblance in the leaf alluded to by Gerarde, possibly also the toughness of the wood, seem to have led to these trees being associated with it. The wood of the service-tree is compact and strong, and has been used to make weavers' shuttles.

There is another species of the tree indigenous in the south of England, known as the wild scrvice-tree, with heart-shaped, serrated, seven-lobed leaves, the berries of which are more brown and acid than those of Pyrus domestica. 
The name of service-tree, or servise, is derived from the Latin cervisia, its fruit having been formerly used for making a kind of fermented liquor. "The cerevisia of the ancients was made from malt, and took its name, we are told by Isidore of Sevilie, from ceres, cereris; but this has come to be used in a secondary sense, without regard to its etymological meaning, just as in Balm-tea we use tea in the sense of an infusion, without regard to its being properly the name of a different plant" (Prior). Evelyn says that "ale or beer brewed from service berries when ripe is an incomparable drink."

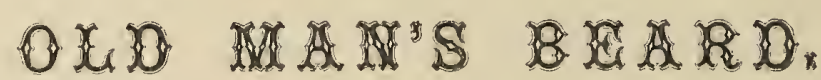

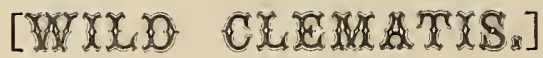

\section{(Clematis Vitalba.)}

\section{"The clematis, the favour'd flower,}

That boasts the name of virgin's bower,"

Is honoured with more than one significant familiar name, descriptive of its appearance or popularity. It is best known in the south of England, where it often grows wild, twining its woody, angular stems among the hedges. Its heart-shaped leaves have also twining stalks. Its flowers are white and scented, but it is most famous for its seeds, which have a long, feathery, silky tail, and give it the appearance which has won for it the name of "old man's beard."

The botanic appellation is from clema, a vine shoot, owing to the resemblance of its creeping shoots to those of the vine.

Gilpin calls it an " elegant climber," and classes it among the " humble plants which live entirely on their own means, yet, spreading out their little tendrils, beg merely the protection of the great, whom, if they encumber, as they certainly do in a degree, they enrich with a variety of 
beautiful flowers and scarlet berries." The clematis has not, indeed, the latter to boast of, but its feathered seeds are ornamental, and many

"An oaken stock in winter woods,"

is "flourish'd o'er with hoary clematis." Although a wild plant it is much valued and cultivated, and there are many foreign species which have to be treated as greenhouse plants in this country. They all require a light soil. The hardy kinds are well adapted for trellis-work, or training against a wall. The ordinary clematis is very commonly seen flourishing on the walls of cottages in the south of England, and is a striking ornament to country villages. Brooke, in his edition of Culpepper's Herbal, in a spirit inimical to our age of progress, says: "In good old times in England, when labourers had cottages and gardens, when they had self-respect, when dukes would as soon have thought of hanging them as to offer them ' curry powder' instead of bacon, or to consign them to the tender mercies of a union workhouse, after having spent the prime of their lives in hard work, scarce a labourer's cottage was to be seen which was not covered with the vine, the hop, or the traveller's joy." The name of "traveller's joy," some say, is owing to its appearance being hailed by travellers as significant of the vicinity of human dwellings, but Gerarde claims to have given it the name himself, saying it is "called Viorna, quasi vias ornans, of decking and adorning ways and hedgerows where people travel, and therefore I have named it the traveller's joy. These plants have no use in physic as yet found out, but are esteemed only for pleasure, by reason of the goodly shadow which they make with their thick bushing and climbing, as also for the beauty of the flowers, and the pleasant scent of the same."

It still retains in some parts of England the name of "Virgin's bower." Lady or virgin in the old English names of plants almost always has reference to the Virgin Mary, but in the present instance it may have been given by Gerarde in allusion and compliment to Queen Elizabeth, when he was superintendent of Lord Burleigh's botanical garden.

The juice of the clematis, it is said, will raise a blister on the skin from its acrid nature. It grows chiefly on chalky soil.

The little red beetle in our picture is one of the species called sunbeetles, which show themselves on sunny days, when their shining coats 
reflect the light. It belongs to what have been expressively termed "the starred and jewelled nobility" of the insect world, so many of them being remarkable for their brilliant colouring, especially under a microscope, when they look as if they were sprinkled with precious gems.

The order of beetles, of which there are recorded upwards of 3,000 British species, stands first among the insect tribes, chiefly on account of the great perfection of their insectile structure. They are distinguished by having a mouth armed with two pairs of powerful jaws, which move horizontally, and their strong, horny fore-wings, in which their brilliant beauty is situated, forming sheaths for the gauze-like hind pair. Many beetles do not attain their maturity till the summer is over; they then, after enjoying the few remaining mild days, retreat to some safe retirement, to sink into their winter sleep, and reappear in spring. Hence they are much more frequently seen in autumn and spring than in the height of summer.

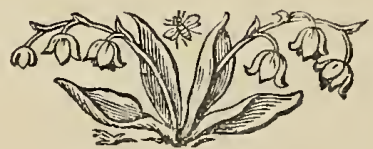




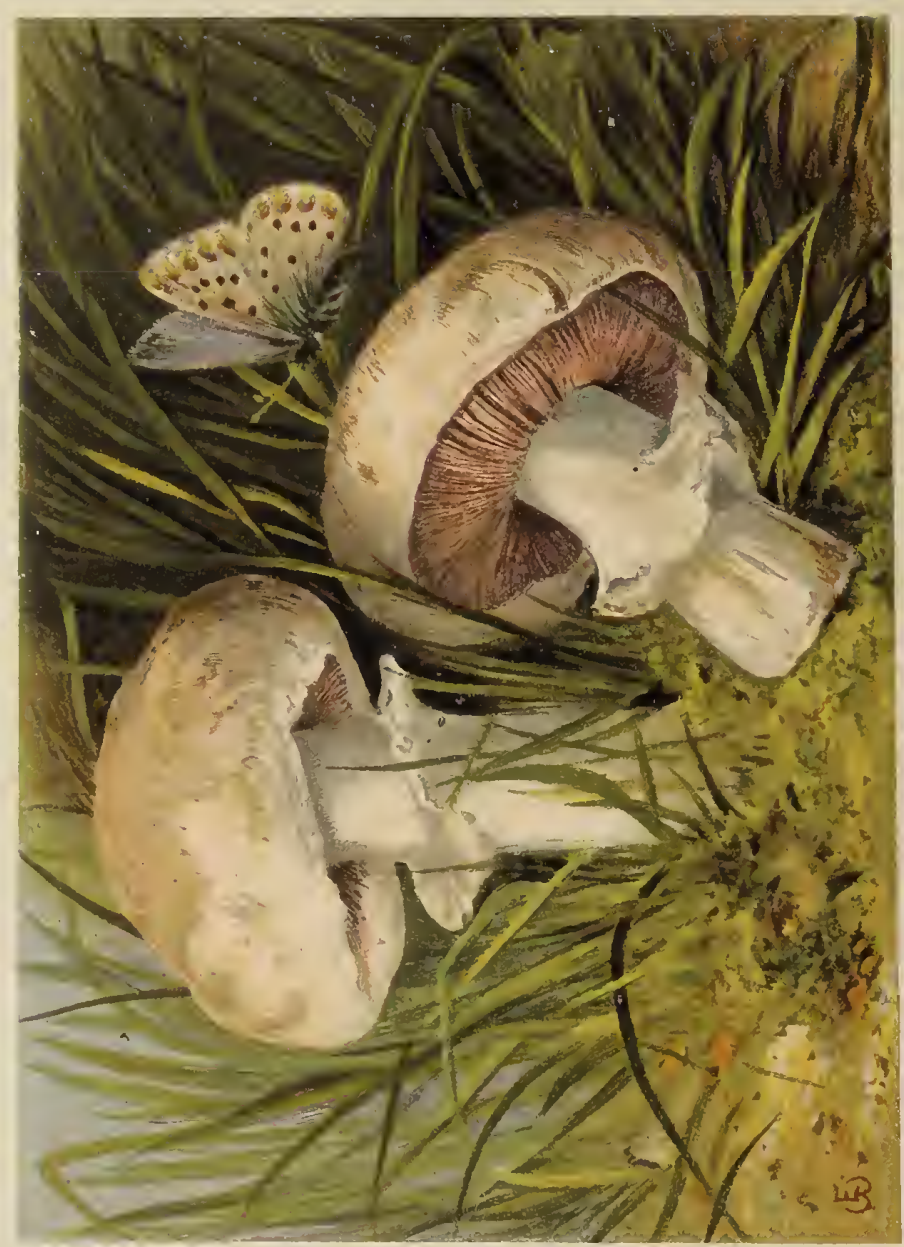




\title{
W
}

\author{
(Agaricus Campestris.)
}

IS
kind which many of us can entertain the idea of eating; yet we
are told that amongst the five thousand sorts of fungi in Great Britain the major part are good for food. We are far from wishing to endorse this opinion, as we have before explained. Still it is a curious fact that the species recognised as wholesome by us is rejected in foreign countries, and vice versâ. Our mushroom goes among Italians by the name of "Pratiola," and "May he die of a pratiola" is the worst wish of an Italian for his enemy. In Rome there is a regular market for the sale of fungi, and an inspector to see that no poisonous kind is cxposed for sale; and we are told by Dr. Badham that "whilst many hundred baskets of what we call toadstools are carried home for table, almost the only one condemned to be thrown into the Tiber is our favourite mushroom."

In Milan and Vienna it is recognised as wholesome, and freely eaten; but in Hungary it is rarely seen, whilst the Boletus, usually rejected in England, is very popular.

In France, our mushroom is the one most commonly eaten, although other sorts are more freely used than in our own country.

A mushroom, like other fungi, may be described as a plant without flowers, composed of cells, and receiving its nourishment from the earth through the stalk. Its chemical properties are, we are told, "water, nitrogen, fatty or animalised matter, sugar, aromatic substance, sulphur, silex, and a substance not clearly defined, which turns brown on being exposed to the air." 
Uninviting and mysterious as this combination sounds, there can be no doubt that the flavour of the common mushroom is most delicious, and supplies a relish to almost any meal when well cooked. This condition is indispensable.

The extraordinary rapidity of the growth of these plants is a noticeable fact in regard to them. A field which has appeared quite bare the night before will be found covered with them in the morning. This gave rise, in old times, to the belief that their production was the work of fairies during the night. Thus Prospero is represented addressing them as-

"Ye elves of hills, brooks, standing lakes, and groves,

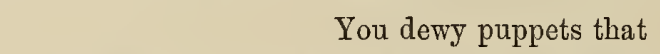

By moonshine do the green sour ringlets make,

Whereof the ewe not bites; and you whose pastime

Is to make midnight mushrooms."

Tempest.

Another idea was that they served as their dining-table.

" Upon a mushroom's head

Our table-cloth we spread."

King and Queen of the Fairies, 1635 (Percy's Reliques).

Though these illusions havc been dispelled by the "cold, material laws" of science, the mushroom-gatherer still goes forth at early morn-

"When, glittering in the freshen'd fields,

The snowy mushroom springs;"

for the impression prevails in some districts that they mclt away under the sun's rays.

Under the name "mushroom" are included, in England, all the edible species. The principal of these are, according to Dr. Badham (Esculent Fungi of Great Britain) :-

Fistulina hepatica, the liver fungus-so called from its colour. It grows on the trunks of old oaks, has the appearance of a tongue, and when young, if sliced and grilled, is said to pass for beef-steak.

Lycoperdon giganteum-giant puff-balls-are highly recommended, 
but, it must be observed, only when young and pulpy. When the cut surface is white as snow, if sliced and fried in butter it resembles sweetbread, but should be rejected if any yellow marks or stains are visible. This kind is very popular in Italy.

Hydna, another kind of puffs, resembling oysters in taste.

Lactarius deliciosus, said to be the most delicious mushroom known.

The yellow Chantarelle (Cantharellus cilarius), of a bright, deep yellow, smelling like apricots. On the Continent this mushroom is very highly esteemed.

Boletus edulis, belonging to a class of which there are thirty British species, enjoying a doubtful reputation; but the wholesomeness of this individual seems unquestionable.

Russula heterophylla, pronounced to taste like crawfish when grilled; and another species of the same genus, Russula virescens, of a greenish colour. The latter is preferred in France to the ordinary mushroom. It is common in Languedoc, where it is called Verdette.

Whilst endeavouring to do justice to a too much neglected natural produce, we cannot help observing, in conclusion, that the cautions which accompany the recommendation of edible fungi by connoisseurs, and the appalling results related as possibly ensuing on any mistake in selection, may well make nervous persons satisfied with a more recognised article of diet.

The origin of the word mushroom is said to be from the French mousseron, a name given on account of its growing amongst moss. It is in France, however, applied to but one species, whilst the general term is champignon, which with us designates one kind only - the fairy ring champignon, from its causing those circles in the grass formerly supposed to be used as the dancing grounds of fairies. These rings are, it is believed, first formed by a single fungus, "whose growth renders the soil immediately beneath unfit for reproduction. The spawn, however, spreads all around, and in the second year produces a crop whose spawn spreads again, the soil behind forbidding its return in that direction. Thus the circle is continually increased, and extends indefinitely till some cause intervenes to destroy it" (Rev. M. J. Berkeley).

The term Agaric has been supposed to be derived from Agaria, a region in Sarmatia, but Mr. Berkeley seems to prove that this origin is very 
indirect. According to him, the word Agaricum was applied by Dioscorides, the eminent physician and botanist of the first century, to a peculiar drug obtained from the polyporus of the larch. It was principally brought from Agaria, but is now almost entirely out of use. Other polypori have often been substituted for that of the larch, and therefore the name Agaricum, or Agaricus, as it was afterwards written, became, to a certain extent, generic for polyporus.

Our pretty little delicate butterfly may be seen in most country neighbourhoods, careering over heathy downs, during any part of the summer from May to the end of September. It is the common blue (Polyommatus alexis). Its upper side, in the male insect, is a lilac blue, in the female more of a purplish shade, and brown towards the centre; the under side in both sexes pale grey, with brownish spots, sometimes with a border of orange-red spots. Its principal food is the bird's-eye trefoil. It emerges from a green caterpillar, with a stripe down the back of a darker shade, and spotted with white on each side.

This lovely little insect may often be mistaken for a blue flower as it rests among the blossoms; and, as it flits away, almost invites a chase from those who think only of the prize and not of the greater pleasure of witnessing its airy flight. Surely the reflection that we could not replace one out of its many thousand fairy-like plumes, might make us fear

$$
\text { " to brush }
$$

The dust from off its wings."

The glorious colours of our butterflies have often suggested the thought of what unimagined splendours may be awaiting our spiritual vision, when such prodigality of beauty is lavished on forms which often pass unnoticed by the unappreciating eyc of man; and with reference, not to butterflies only, but to the other natural objects which have occupied our attention, we are reminded of the words of one of the most eloquent of our sacred poets :-

" O God! O good beyond compare!

If thus Thy meaner works are fair;

If thus Thy bounties gild the span

Of ruin'd earth and sinful man;

How glorious must the mansions be

Where Thy redeem'd shall dwell with Thee!" 


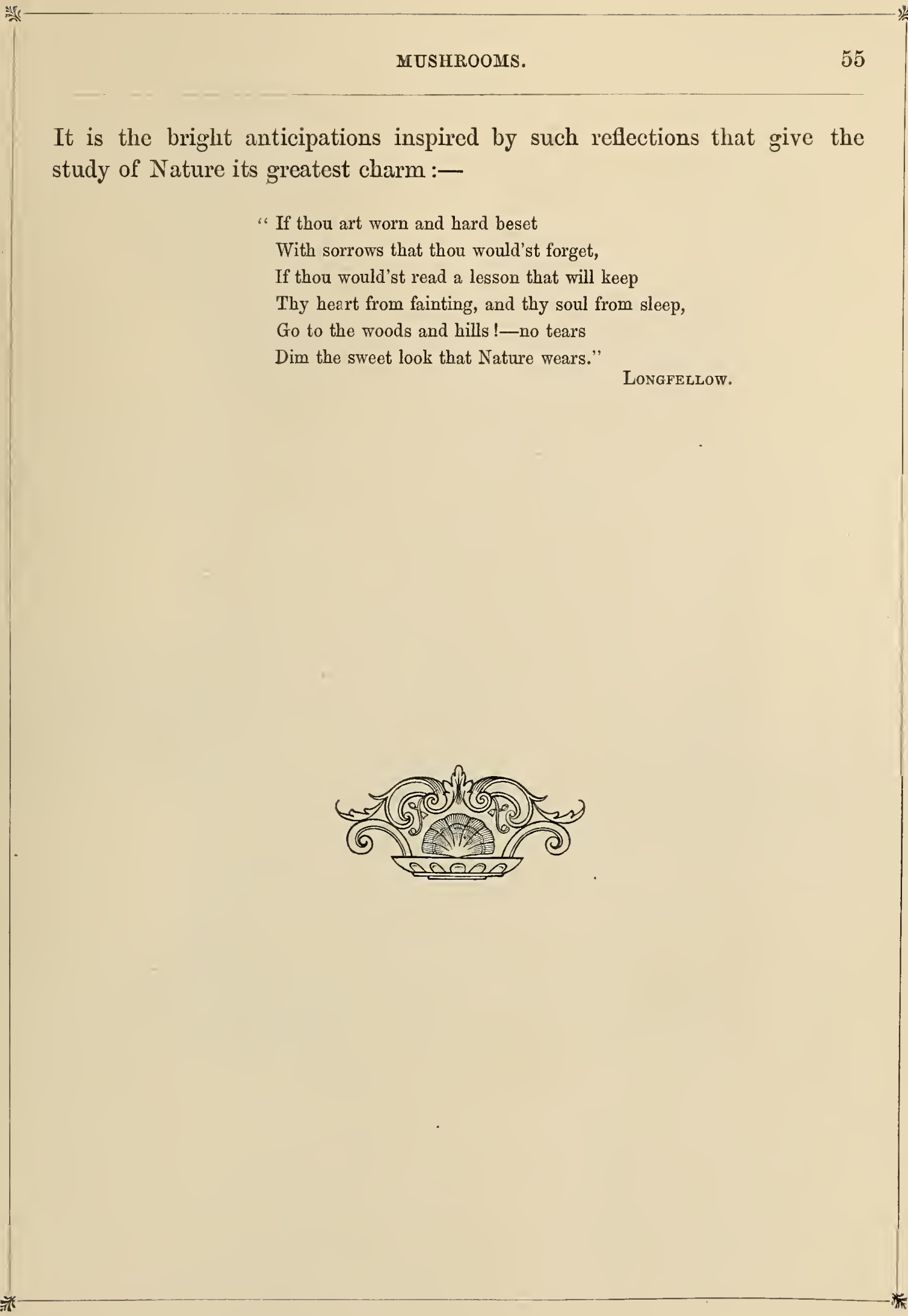


LONDON

Painted bi Jas. Truscott and Sos, suffolk Lane, City. 


